مقاومة التغيير التظظيمي لدى أعضاء الملاك الإداري والتدريبي في الأندية

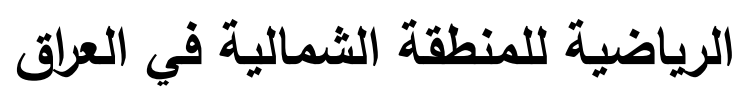

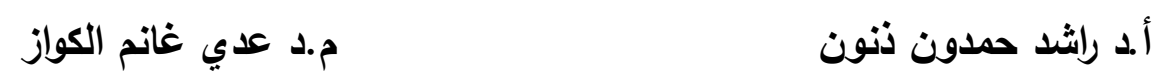

كلية التربية الرياضية / جامعة الموصل

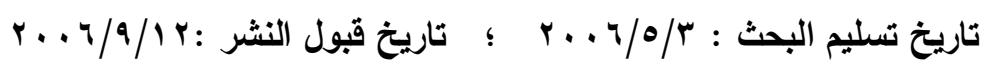

ملخص البحث

هاف البحث إلى :

ا. بناء مقياس القيم الإدارية لأعضاء الملاك الإداري والتدريبي في الأندية الرياضية للمنطقة

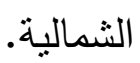
r. التعرف على القيم الإدارية لاى أعضاء الملاك الإداري والتدريبي.

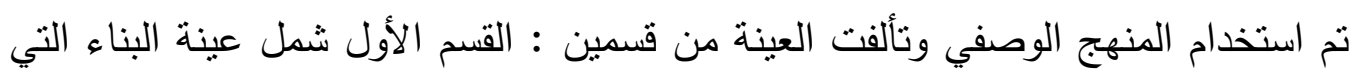

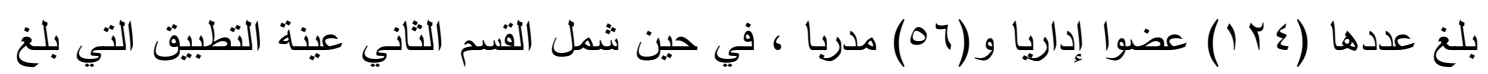

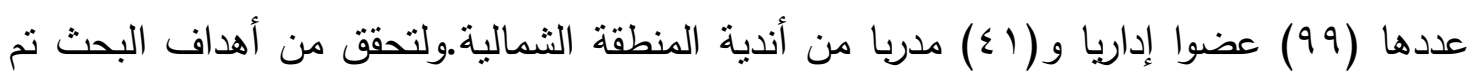

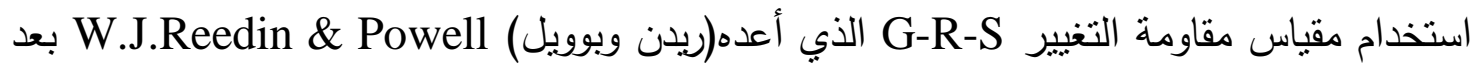
تعديله والتحقق من صدقه وثباته. تمت معالجة البيانات إحصائيا باستخدام التحليل ألعاملي و قانون

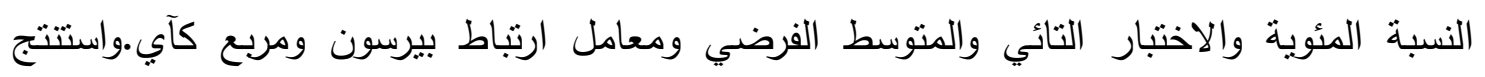
الباحث ماياتي : البنة ا ـ لاتوجد علاقة معنوية بين نوع الملاك (إداري-تدريبي) ومقاومة التغيير بسبب العوامل التتظيمية

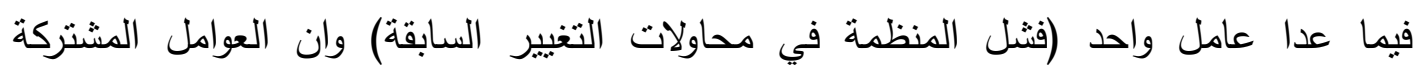
والمسبية لمقاومة التغيير بالنسبة إلى الملاكين هي (احتمال بقاء نظام المكافآت).

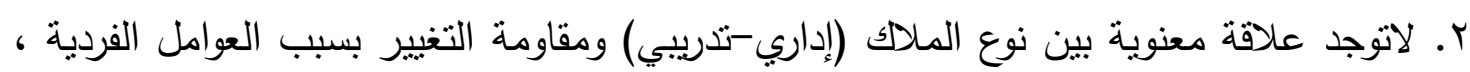

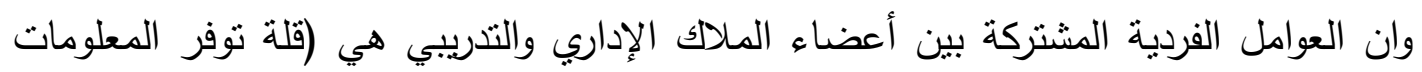
وعدم فهم أهداف التغيير ، تضارب الأهداف الفردية والتتظيمية). 


\section{The resistance of the change among the administrative and training staff members in northern region sport clubs in Iraq}

By

Prof.Dr. Rashed.H.Thanoon

lecturer.Dr. Auday C.M.AL-Kwaz

University of mosul - college of sport education

\section{Abstract}

The study aims at:

1.Relation between staff type (administrative-training) and organizational factor lead to resisting change.

2.Relation between staff type (administrative-training) and individual factor lead to resisting change.

Descriptive approach has been used in the study. The study sample consists of two parts. The construction part includes (124) administrative members and (56) coaches. The application parts includes (99) administrative members and (41) coaches. Change Resistance Scale (GRS) prepared by Reedin and Powell after modification has been adopted to realized the study aim. Data have been statistically handled using percentage, mean, T-test, Pearson correlation coefficient, chi-square and factor analysis.

The study concludes with the following:

1. There is no significant relation between staff type (administrativetraining) and change resistant as result for organizational factor except one factor (the organizational failure in previous changing trials) and the factor which take part and result to change resistance between tow staff are (motivation system survival probability).

2. There is no significant relation between staff type (administrativetraining) and change resistant as result for individual factor, the individual factors which take part between tow staff are (information lightly and do not understanding change aim, clash individual and organizational aim) 


\section{1- التعريف بالبحث}

1-1 المقدمة

يقول علماء الاجتماع : " الثيء الوحيد الذي لا يتغير هو التغيير نفسه ". ذلك أن التغيير حالة مستمرة تحصل بفعل إرادي أو غير إرادي عن قصد أو غير قصدي الوحد بتخطيط مسبق أو بصورة عفوية تلقائية أو بحكم الظروف وقد يكون التغيير في البيئة الداخلية أو الخارجية بكل التئل انعكاساته

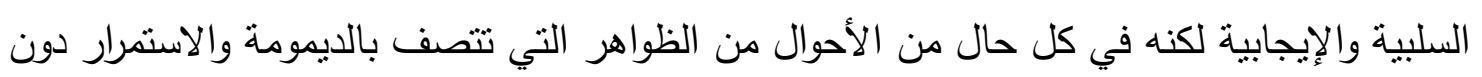
أن تتوقف عند حد معين وقد يكون التغيير بسريانه منظما كجريان الماء أو موسميا على قفزات نوعية الإلية أو كمية وقد يكون بطيئا أو سريعا أو درامانيكيا.

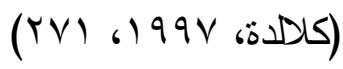

ومن المعروف أن الحركة الرياضية في العراق مرت بفترات ازدهار على المستويات كافة

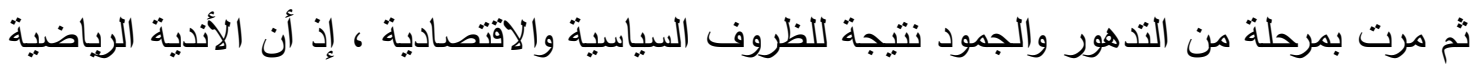

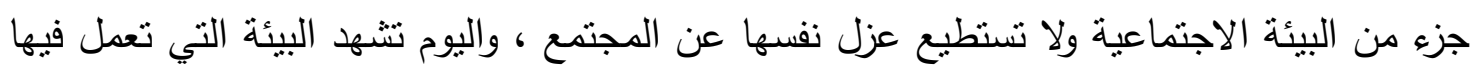

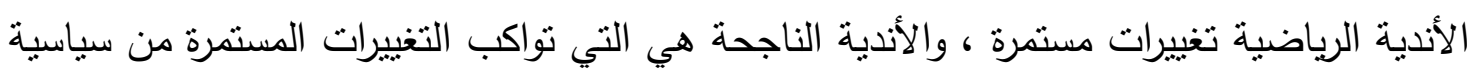

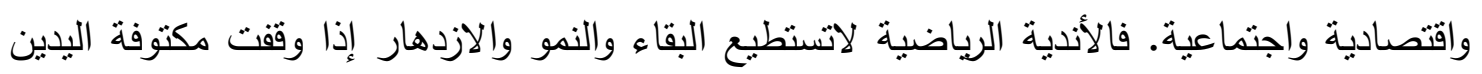

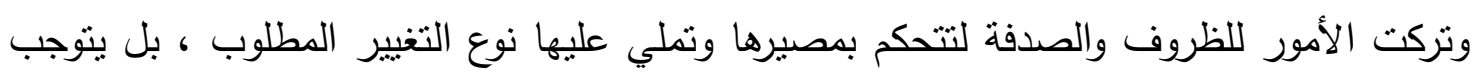
على إدارات الأندية السعي الجاد لإدارة عملية التغيير وتخطيطها ، فمن خلال الجهود الواعية ولئه

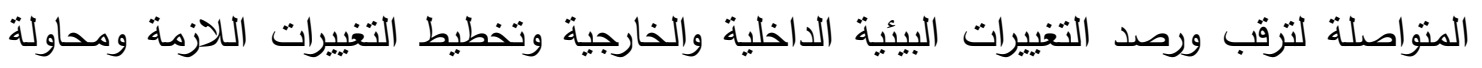

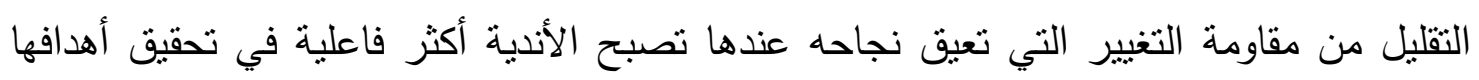
والاضطلاع بمسؤولياتها. وتكمن أهمية البحث الحالي في تتاوله مقاومة التغيير التنظيمي في ظل ثورة التغيير التي

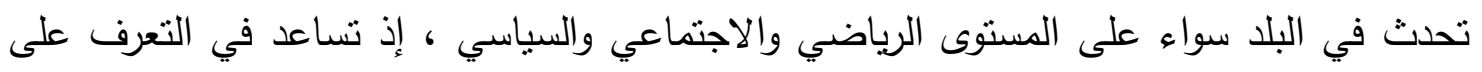

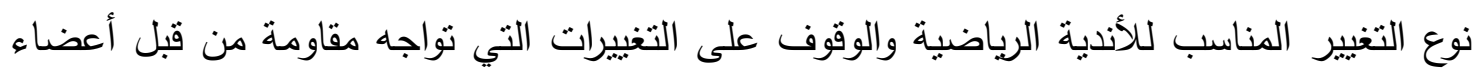

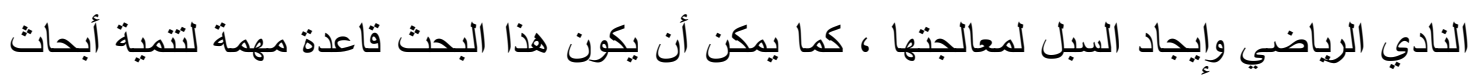

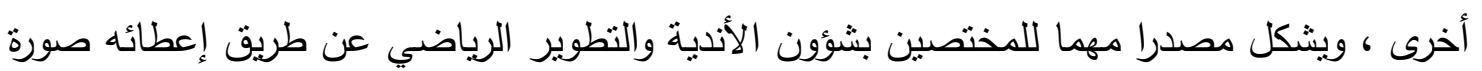
واضحة عن مقاومة التغيير التنظيمي. 
نعيش اليوم في عالم متغير وسريع على كافة المستويات ونلاحظ إن هنالك عدم استقرار

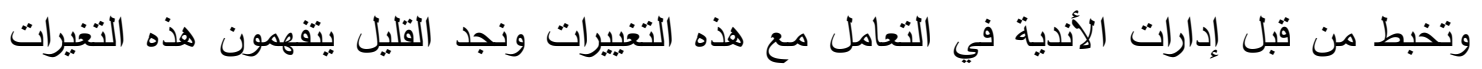

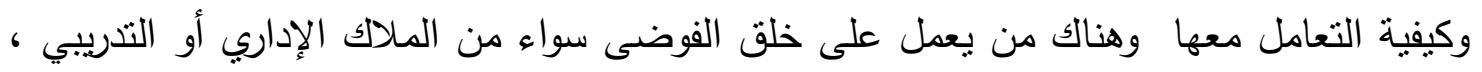

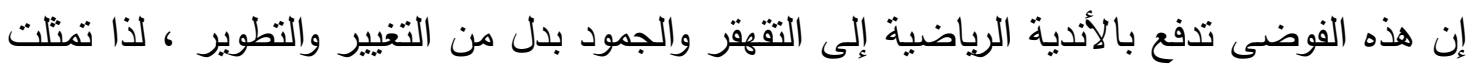

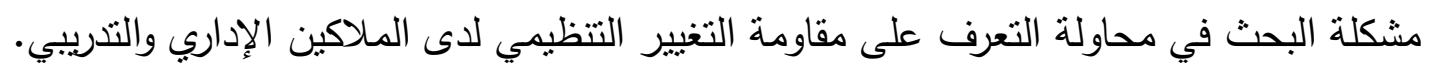
ا

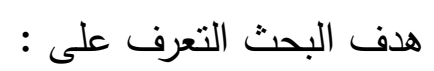

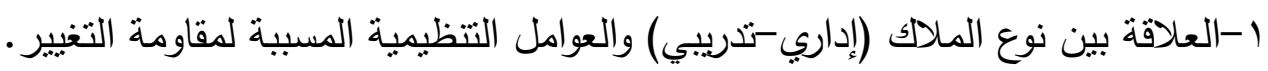

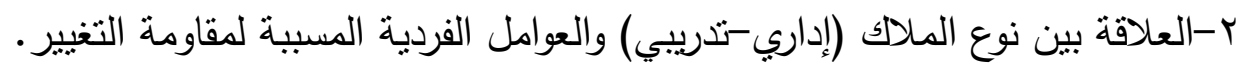

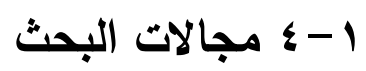

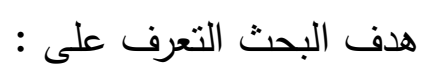

1-المجال البشري : أعضاء الملاكين الإداري والتدريبي في الأندية الرياضية للمنطقة الثمالية.

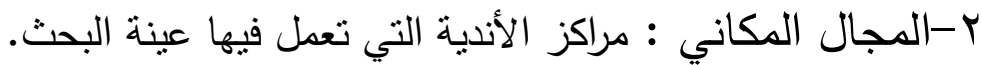

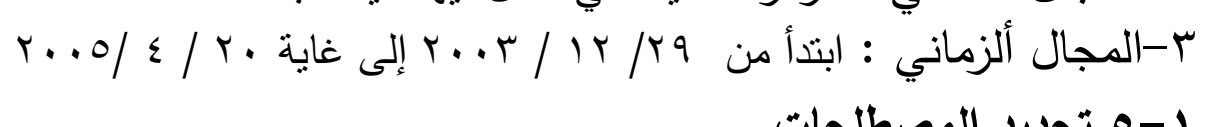
1- 1 - تحديد المصطلحات

مقاومة التغيير التظيمي : Organizational Chang Resistance

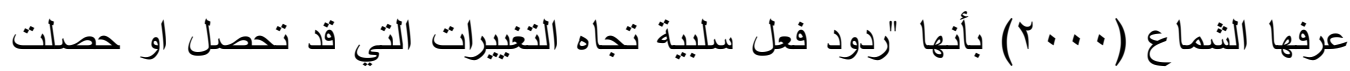

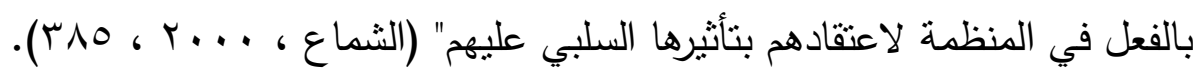

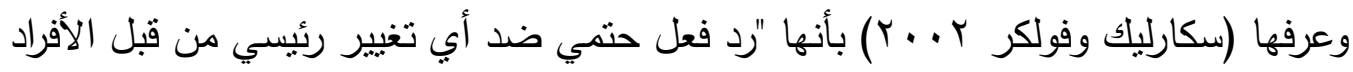

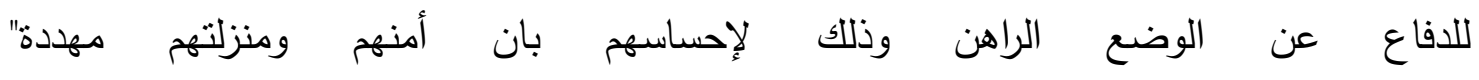
.(Skarleck\&Folger,2002,3) وعرفها (كولا بيرج ودنت ب . . r) بأنها "السلوك الذي يسلكه الفرد لحماية نفسه من تأثيرات التغيير الحقيقية أو الوهمية" (كولد وبيرج (Coldberg\&Dent,2003,27). ويعرفها الباحث إجرائيا بأنها: حالة ادراكيه عاطفية نابعة من أفكار واعتقادات سلبية حول

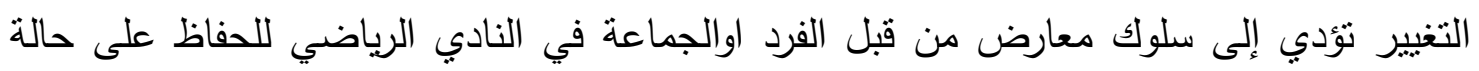
النوازن التي قد تعودوا عليها. 
ب - 1- الإطار النظري

Y - 1 - 1 مفهوم مقاومة التغيير التنظيمي

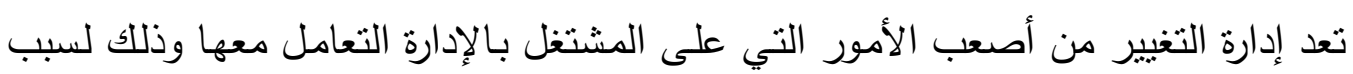
بسيط هو أن الناس يفضلون ما اعتادوا عليه لذا فان الرد الطبيعي على التغيير في اغلب الأحيان

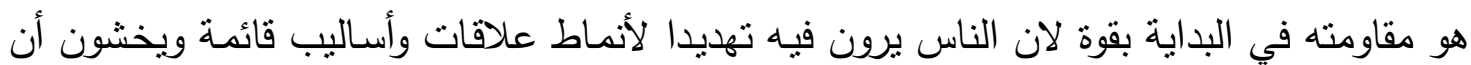

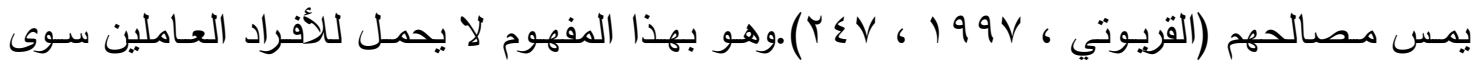

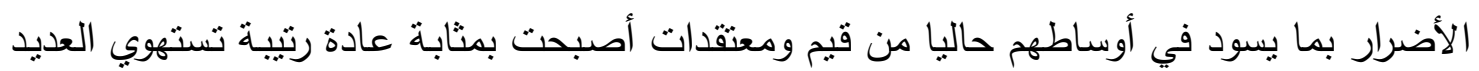

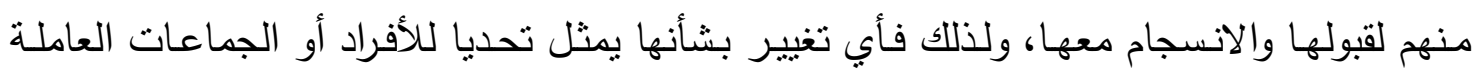

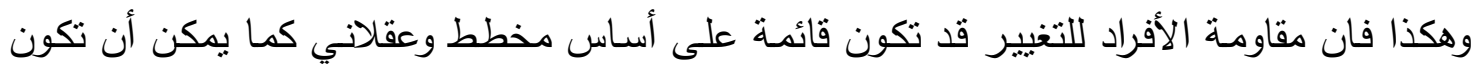

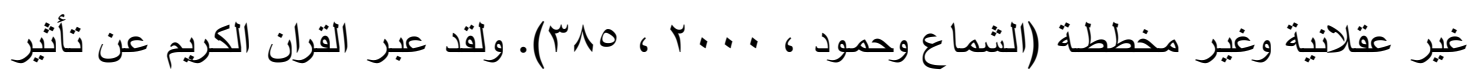

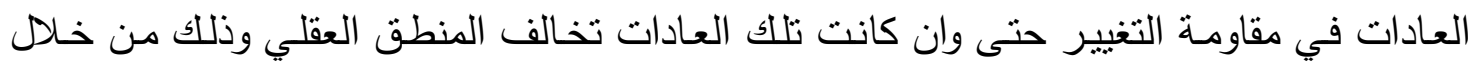

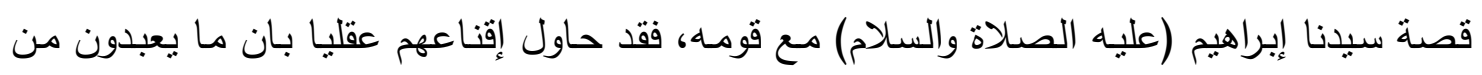

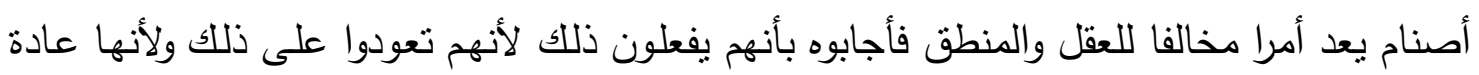

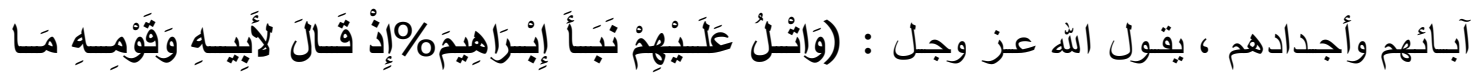

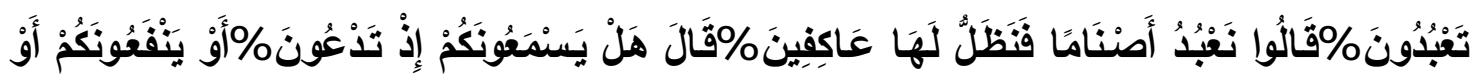

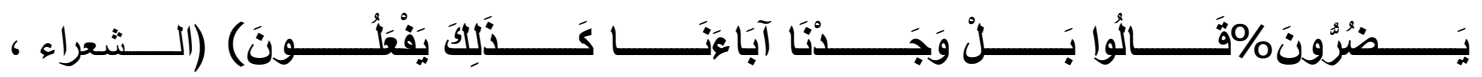

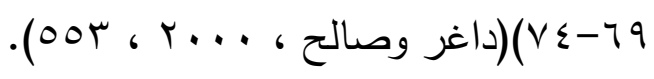

r r r r أسباب مقاومة لتغيير

هناك أسباب عديدة قد تدفع الفرد لدقاومة التغيير التنظيمي قسم منها ناشئ عن التهابر

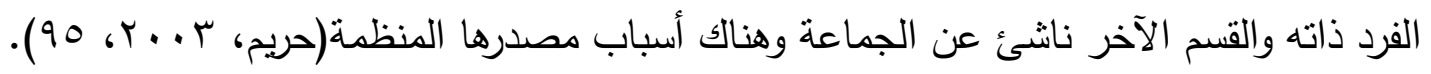

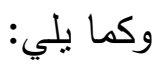

ا ـ المصادر الفردية لمقاومة التغيير :

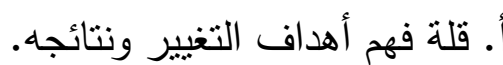
ب. القصور في معرفة الحاجة إلى التغيير . ج. الخوف من فقدان المركز الوظيفي أو السلطة التي يملكها جراء التغيير.

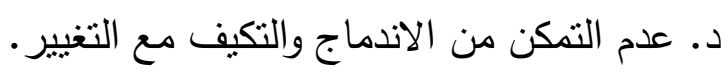
هـ. صعوبة تغيير العادات التي اكتسبها الفرد. 
و . تهديد التغيير للعلاقات الاجتماعية القائمة. ز • قواعد سلوك الجماعة وصعوبة التحلل منها. ح. تضارب الأهداف الفردية مع الأهداف الجماعية (مصطفى ، I9AV ، بع). وهي المصادر التي اعتمدت في هذا البحث. وهناك من يرى أن مقاومة الفرد أما أن تكون لأسباب أساسية نفسية استتادا إلى أحاسيس الفرد واتجاهاته أو لأسباب اجنماعية على أساس قيم ومصالح جماعة العمل. وكآلاتي: أ- الأسباب النفسية لمقاومة الفرد للتغيير : لهابه - الخوف من المجهول : إن مفاجأة العاملين بالتغيير دون وجود معلومات كافية لديهح عن طبيعته وستولد شعورا بالتهديد وعدم الاستعداء لله وستزيد من الإشاعات مما يولد مقاومة ضده

.(Kinitar\&Kiniki,1995,272) - العادة : إننا بوصفنا بشر نخلق عاداتتا وذلك بسبب تعقيد الحياة إذ لاناخذ بنظر الاعتبار المدى الكامل من الخيارات لمئات القرارات التي علينا اتخاذها يوميا وللتوافق مع هذا التعقيد في الحياة فإننا نعتمد العادة أو الاستجابة المبرمجة ولكننا حينما نواجه بالتغيير فان هذا الميل إلى الاستجابة بطرقنا المعتادة يصبح مصدرا للمقاومة. - الأمان : الأفراد الذين لايهم حاجة عالية للامان من الممكن أن يقاوموا التغيير، لأنه يهدد شعورهم بالأمان. - عوامل اقتصادية : هي التخوف من أن يؤدي التغيير لانخفاض الدخل إذ أن تغيير مهمات أو روتين العمل يؤدي إلى التخوف الاقتصادي إذا ما اعتقد الأفراد أنهم لن يتمكنوا من أداء المهام بنفس كفاءتهم في أداء مهمات سابقة. - التعامل الانتقائي مع المعلومات : الأفراد يتعاملون مع المعلومات بشكل انتقائي لكي يحافظوا على إدراكهم إنهم يسمعون ما يرغبون سماعه ويهملون المعلومات التي تتحدى عالمهم الخاص

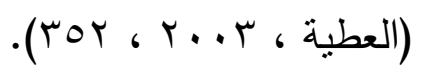
ب. الأسباب الاجتماعية لمقاومة الفرد للتغيير : - يعد التغيير تهديدا للتحالفات أو العلاقات القائمة. - تعارض التغيير مع قيم الجماعة. - محدودية وضيق النظرة. - ثبوت مصالح الأفراد والرغبة في الاحتفاظ بالعلاقات الاجتماعية القائمة. 
(Steers,1989,167 )

r. المصادر التتظيمية لمقاومة التغيير

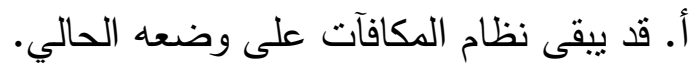
ب. التنافس والصراع بين الأقسام قد يؤدي إلى قلّة النعاون الطوعي.

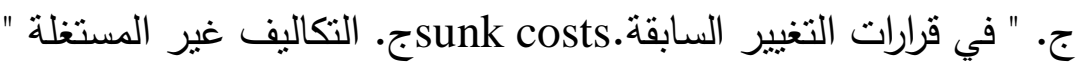
د. كما قد يكون المناخ التنظيمي السائد سببا للمقاومة. هـ. ضعف اختيار الطرائق المناسبة في إدخال التغيير. و . فثل المنظمة في محاولات التغيير السابقة.

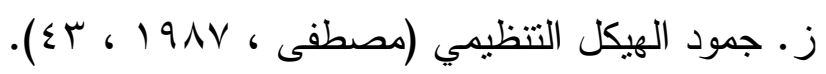

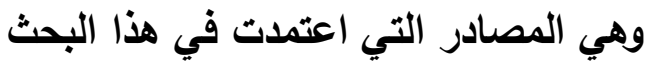

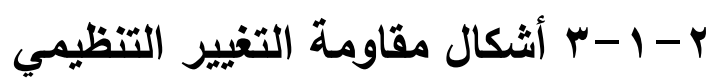
تقع مقاومة التغيير بصيغ مختلفة وأثنكال متفاوتة يمكن تصنيفها على وفق الأسس الآتية:

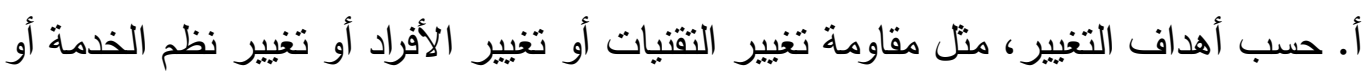
الهيكل التنظيمي. ب. حسب صيغ المقاومة، مقاومة إيجابية، مقاومة سلبية. ج. حسب درجة المقاومة، كامنة، محدودة التأثير (ضعيفة)، قوية.

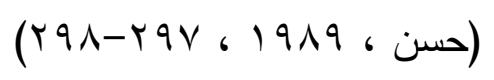
ومن الأشكال الثنائعة في مقاومة الفرد للتغيير : ا ـ قيام الفرد بالتهجم على أية فكرة أو رأي جديد.

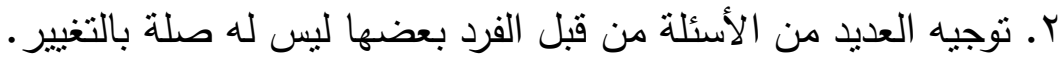
r. يؤدي الفرد دور الصامت ولا يتقوه بثيء. ع. يظهر الفرد انه منزعج وغير قادر على اتخاذ قرار بشان التغيير المقترح.

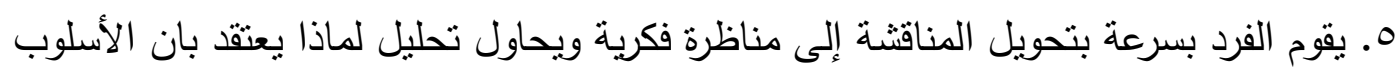

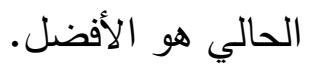
T. يصر الفرد على أن التغيير ليس عادلا.

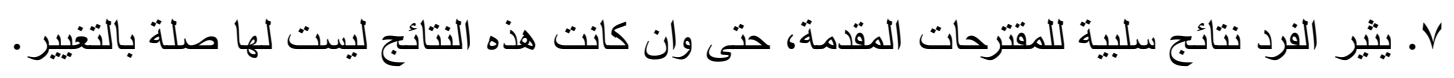

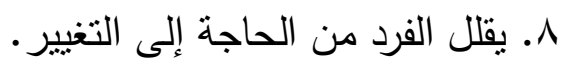


9. يظهر الفرد موافقته الثنديدة ولكنه يعبر عن نقد معذور كأن يقول "يالها من فكرة رائعة .. ولكن".

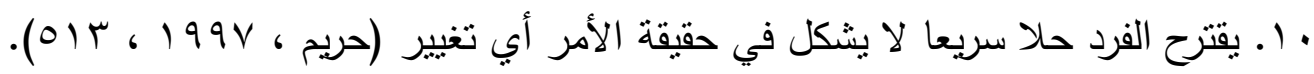

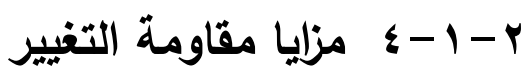

على الرغم من انه ينظر إلى مقاومة التغيير والتطوير على أنها سيئة إلا أن لها نواحي

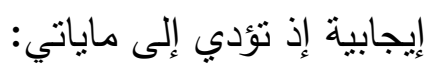
ا ـ تؤدب مقاومة التغيير إلى إجبار إدارة المنظمة على توضيح أهداف التغيير ووسائله وآثاره بشكل

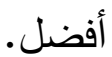

r. تكثف مقاومة التغيير في المنظمة عن عدم فعالية عمليات الاتصال وعن عدم توافر النقل الجيد

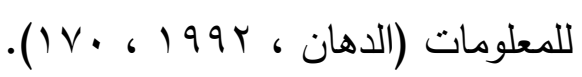

r. يمكن لمقاومـة التغيير أن تشجع الإدارة على تفحص مقترحاتها للتغيير بشكل متعدق وبجديـة متتاهية للتأكد من أنها مناسبة. ـ. مقاومة التغيير يمكن أن تساعد على اكتشاف بعض مجالات ومواطن المشكلات/الصعوبات التي يحتمل أن يسببها التغيير.

ه. المقاومة تزود الإدارة بالمعلومات حول حدة مشاعر الأفراد وشدتها بشان قضية معينة.

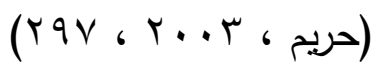

r - - - - معالجة مقاومة التغيير التظيمي

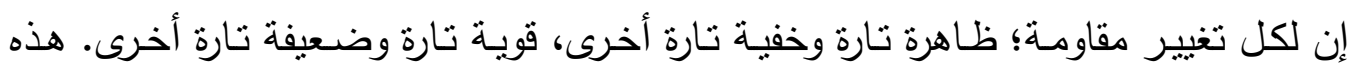

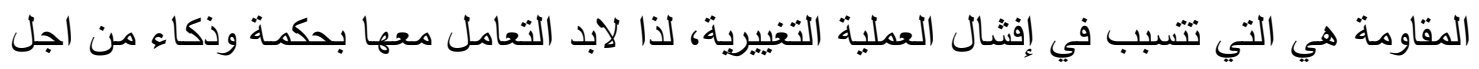

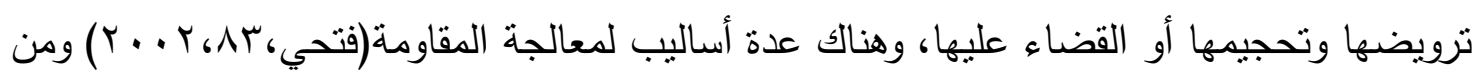

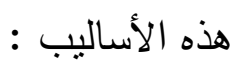

1. التعليم والاتصال : Education and Communication

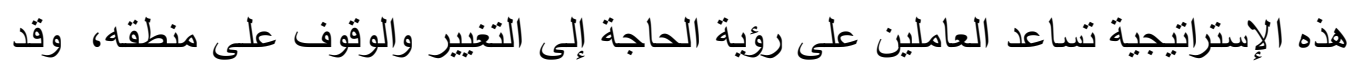

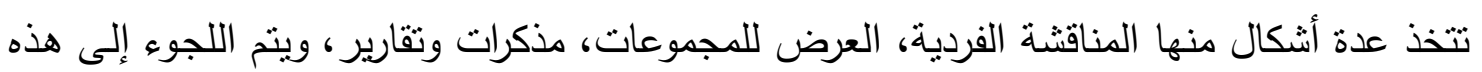

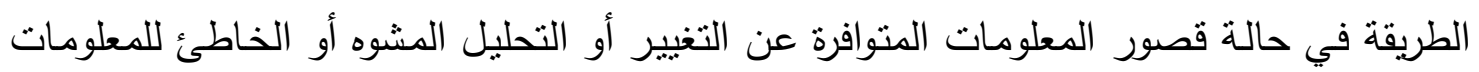

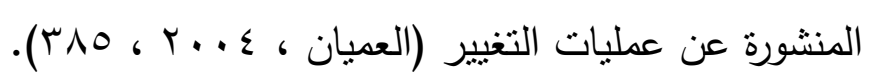

Participation : ب المشاركة

Y) 
وتتضمن السماح للآخرين بالمساعدة في تخطيط التغيير وتتفيذه وتصميمه والطلب من

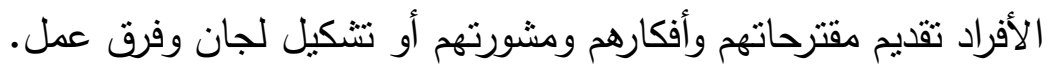

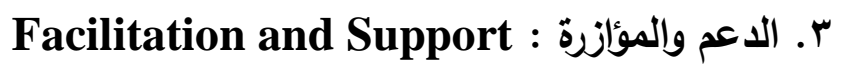

تقديم المساندة الاجتماعية/العاطفية للتغلب على صعوبات التغيير ومخاطره والإصغاء بعناية للكشكلات والتذمر وتوفير النتريب على الأساليب الجديدة وغيرها.

ئ مe التفاوض والاتفاق : Negotiation Acceptance

تقديم الحوافز للأفراد المحتمل قيامهم بمقاومة التغيير وإجراء بعض المساومات ... تقديم

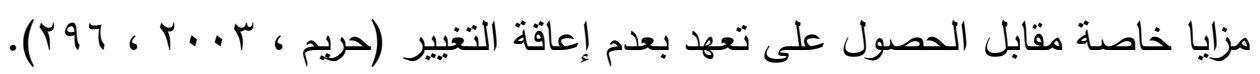

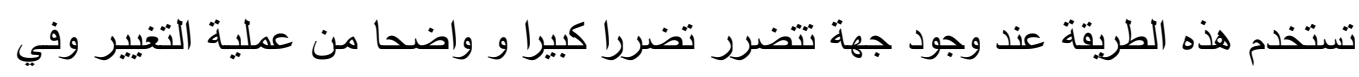

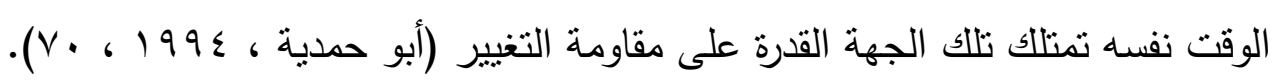

هanipulation and Cooptation : التحكم والاستمالة

وتشمل على استخدام المحـاولات والجهـود الخفيفة للتأثير في الآخـرين وتزويد الأفراد

بمعلومات بصورة انتقائية وترتيب الحوادث بوعي وعقلانية بحيث ينال التغيير المطلوب أقصى دعم ومساندة.

I. 1 الإكراه الصريح والضمني : Explicit and Implicit Coercion ويتضمن استخدام القوة لجعل الناس يتقبلون التغيير، وتهديد أي فرد يقاوم التغيير بأنواع النتائج السلبية المكن اتخاذها بحقه في حال عدم موافقته على الخطة.

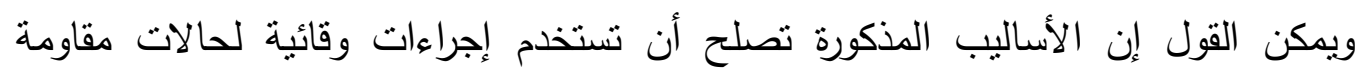

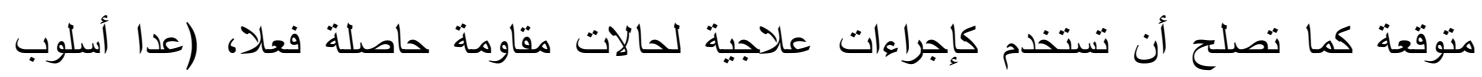

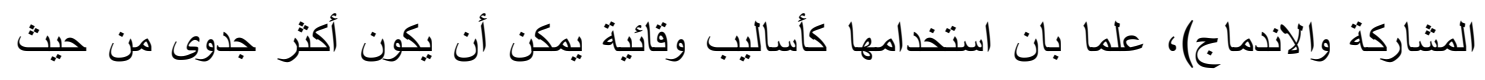

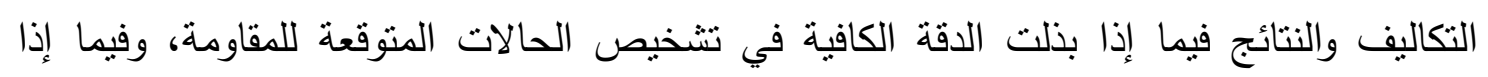

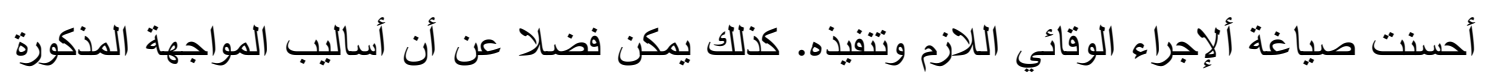

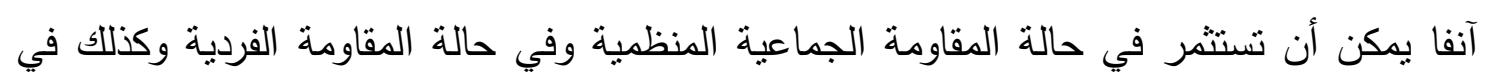

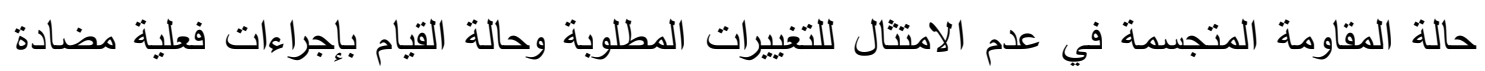

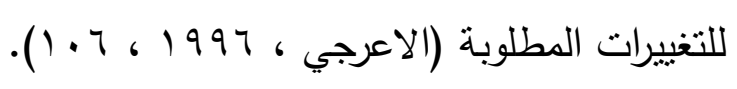
r r r r الدراسات المشابهة 


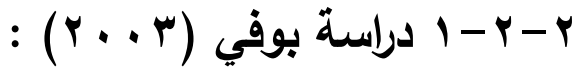

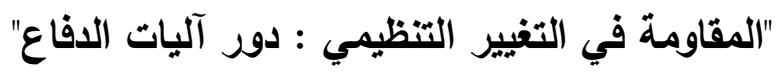

هدف البحث إلى التعرف على العلاقة بين آليات الدفاع (ألنكيفي وغير ألتكيفي) والنيـة

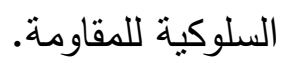

تكونت عينة الدراسة من تسع منظمات تمر بتغيير رئيس وتم الحصول على (10 ال7) إجابة،

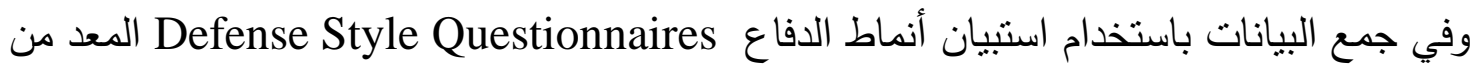
فبل (كونت وبلتجيك) Conte\&Plutchik 1995 للتعرف على آليات الدفاع ، وتصميم استبيان الإدارة الذاتي Administered Questionnaires وفي معالجة البيانات إحصائيا تم استخدام التحليل العاملي وتحليل التباين، واستتتج الباحث

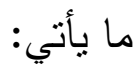
ا ـ لمقاومة التغيير خمس آليات دفاع هي:

أ. آلية المرح : يكون فيها الثخص تكيفي ينعامل مع الضغوط الدئ الداخلية والخارجية بسخرية وتسلية.

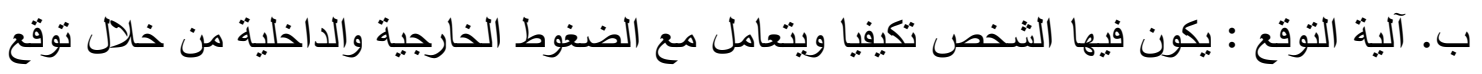

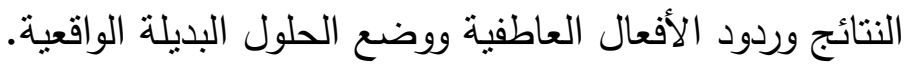

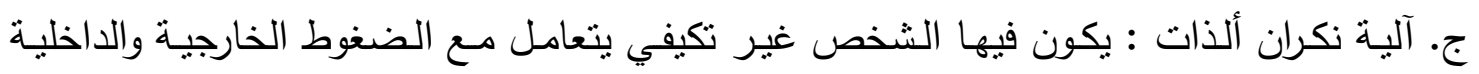
برفض الاعتراف بالحقائق الثخصية المؤلمة الناتجة عن تجارب الآخرين.

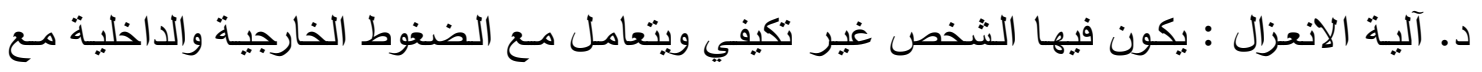

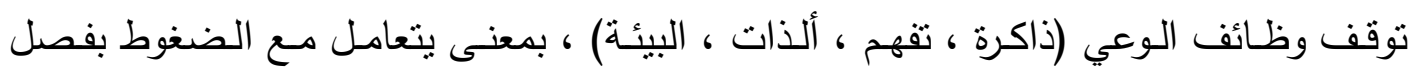

الأفكار عن المشاعر المرتبطة بها أصلا ، أي يفقد الإحساس بالأفكار ولكنه يدركها جيدا.

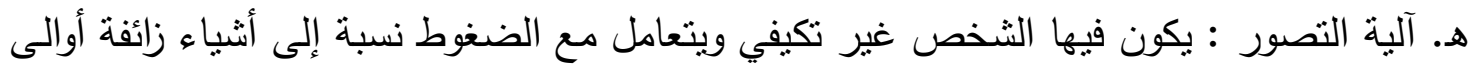
مشاعر خاصة غير مقبولة مثل الاندفاع أو أفكار خيالية. r. آليات الدفاع ترتبط بالنية السلوكية للدقاومة.

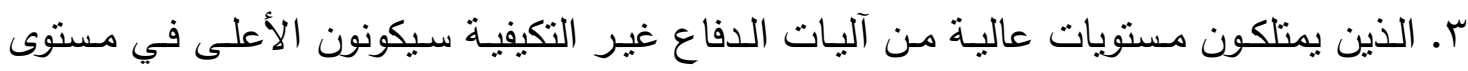
مقاومة التغيير السلوكية. ع. الذين يمتلكون مستويات عالية من آليات الدفاع التكيفية سيكونون الاوطأ في مستوى مقاومـة التغيير السلوكية (Bovey,2003,334-348).

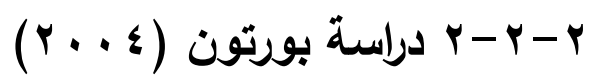

"التوتر ومقاومة التغيير في المناخ التنظيمي والنتائج الإدارية في عالم سريع التغير"

r. 


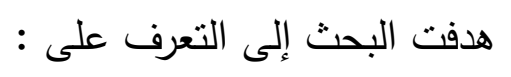

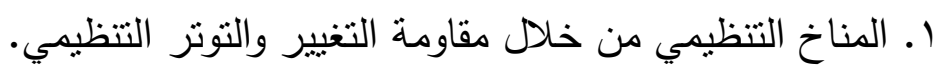

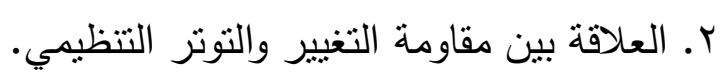

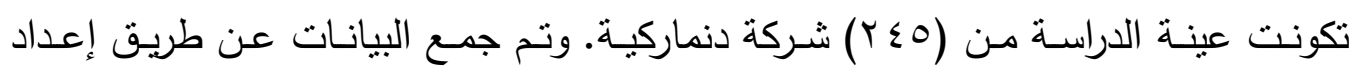

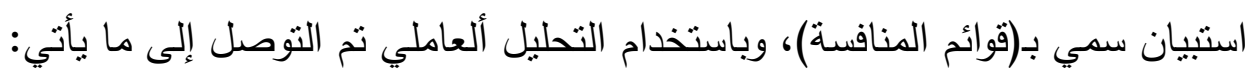

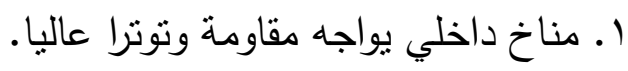

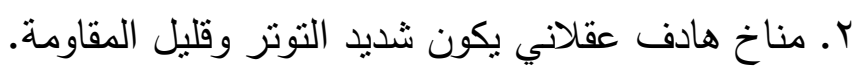

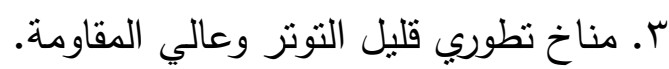

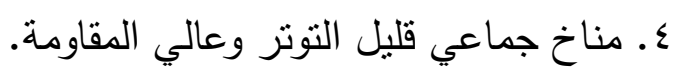

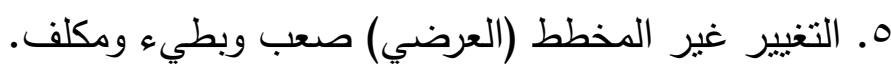

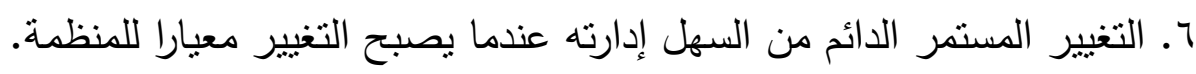

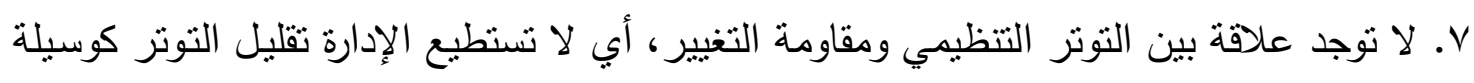
لتقليل المقاومة (17-17, Burton,2004,1).

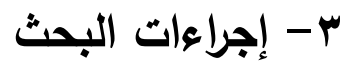 \\ ب- 1 - 1المنهج المستخدم}

لكل منهج وظيفة وخصائص معينة بستخدمها الباحث بما يتلاعم مع أهداف بحثه، و المنهج

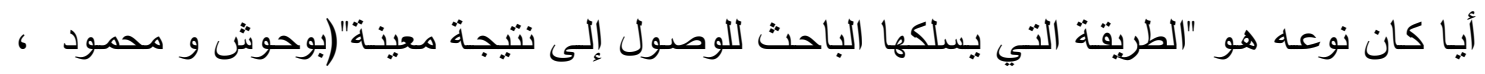

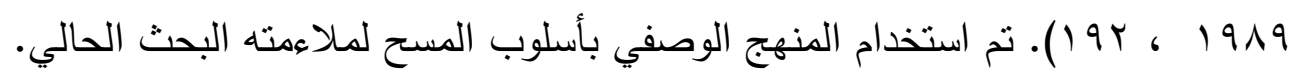

r-r r-r مجتمع البحث وعينته

: r-r 
اشتمل مجتمع البحث على الملاك الإداري والتدريبي في أندية المنطقة الثمالية الموزعة في

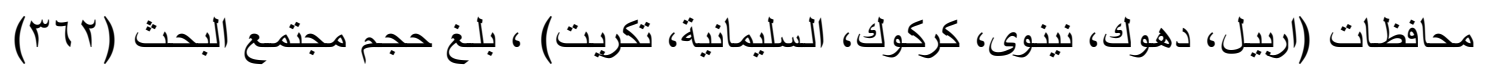

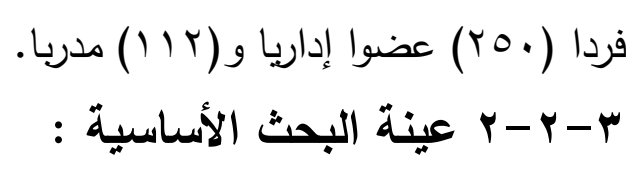

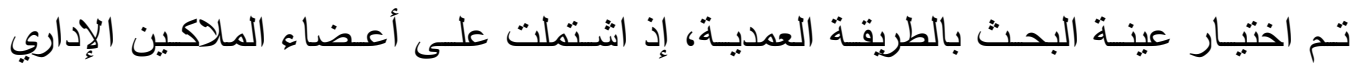

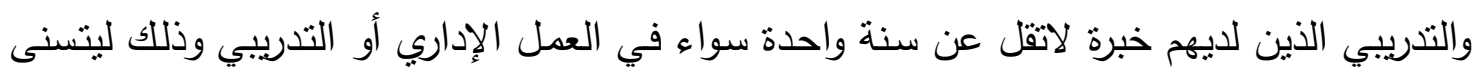

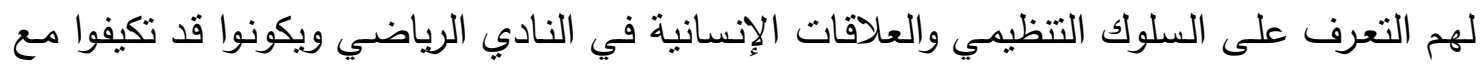

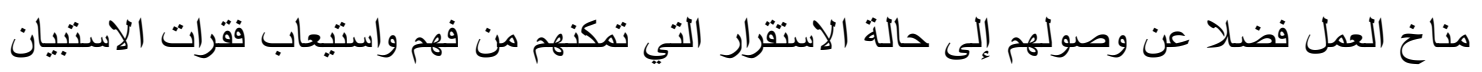

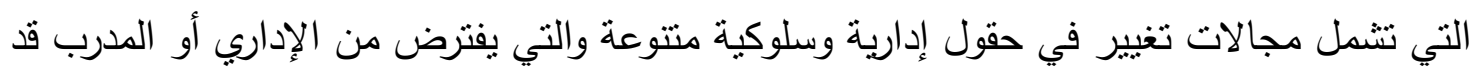

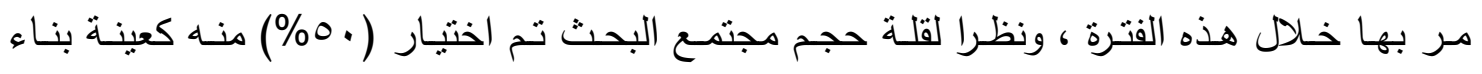

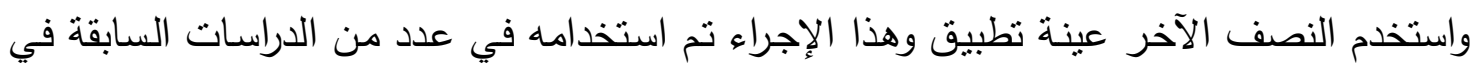

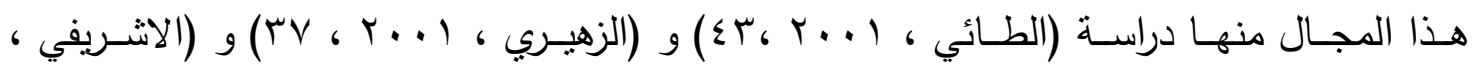
:

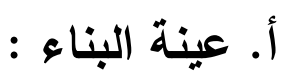

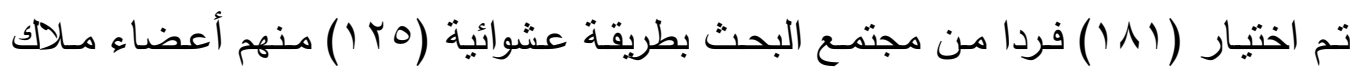

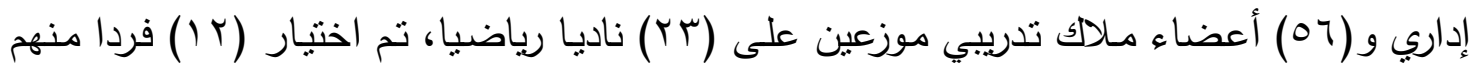

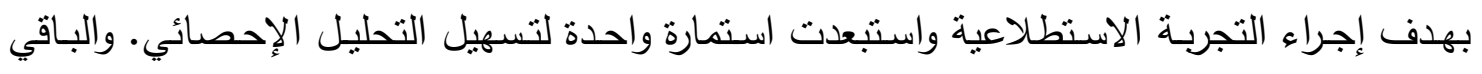

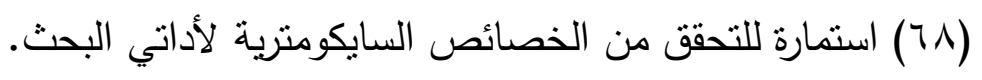

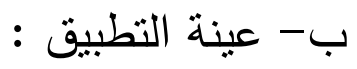
تم تطبيق مقياسي مقاومة التغيير والقيم الإدارية على (1) (1) فردا، (1) (1) (1) منهم أعضاء

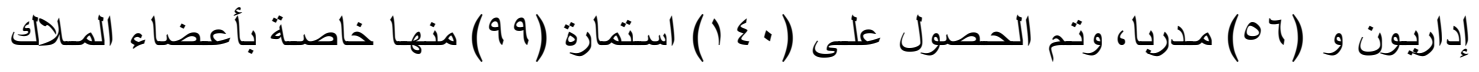

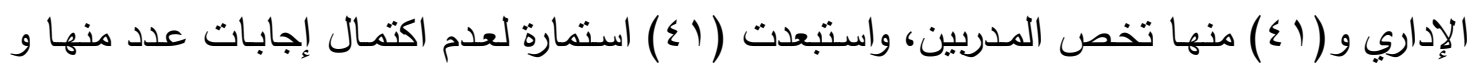
عدم إعادة عدد آخر للاستمارات. والجدول رقم (1) ييين تفاصيل مجتمع البحث وعيناته

(1) الجدول رقم (1) - (1)

يبين توزيع مجتمع البحث وعينة حسب المحافظات الثمالية

TrT 


\begin{tabular}{|c|c|c|c|c|c|c|c|c|}
\hline \multirow{2}{*}{\multicolumn{2}{|c|}{ عينة التطبيق }} & \multicolumn{4}{|c|}{ عينة البناء } & \multirow{2}{*}{\multicolumn{2}{|c|}{ المجتمع }} & \multirow{3}{*}{ المحافظات } \\
\hline & & \multicolumn{2}{|c|}{ عينة ألصدق والثبات } & \multicolumn{2}{|c|}{ عينة التجربة الاستطلاعية } & & & \\
\hline مدريون & إداريون & مدريون & إداريون & مدريون & إداريون & مدريون & إداريون & \\
\hline$\Lambda$ & 11 & 1. & rl & 1 & 1 & $r$. & $\varepsilon \varepsilon$ & اربيل \\
\hline 9 & $r v$ & r & 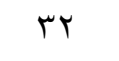 & 1 & 1 & r. & 77 & دهوك \\
\hline $1 \leq$ & $r \varepsilon$ & 11 & rq & $\varepsilon$ & $\varepsilon$ & r. & 77 & نينوى \\
\hline 7 & iv & 9 & rl & ----- & ---- & iv & $\varepsilon 1$ & كركوك \\
\hline$r$ & $\varepsilon$ & r & 0 & ----- & ---- & 7 & 11 & السليمانية \\
\hline r & 9 & $\varepsilon$ & 1. & ----- & ---- & 9 & rt & تكريت \\
\hline$\varepsilon 1$ & 99 & 0. & 111 & 7 & 7 & $11 \mathrm{r}$ & ro. & \\
\hline \multicolumn{2}{|c|}{$1 \leq}$. & \multicolumn{4}{|c|}{11.} & \multicolumn{2}{|c|}{ r } & \\
\hline
\end{tabular}

r-r r r أداة البحث

W.J.reedin \& Powell تم اعتماد مقياس مقاومـة التغيير الذي أعده ريدن وبوويل

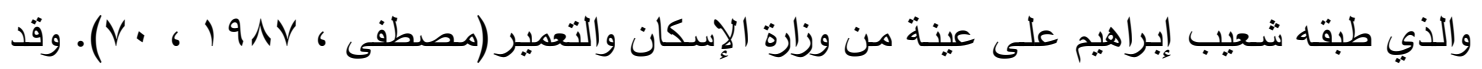
اعثمد الباحث على أداة البحث للمبررات آلاتية : أ. إن المقياس مطبق على البيئة العراقية وبتمتع بصدق وثبات عاليين. ب. يركز على مجالات أساسية من مجالات التغيير الضرورية في الأندية الرياضية. ج. اتفاق آراء الخبراء حول إمكانية اعتماد هذه الأداة في قياس مقاومة التغير في الأندية الرياضية بعد أجراء التعديلات عليه بما بناسب عينة البحث. د. يتميز المقياس بالثمول إذ يتضمن فقرات ممثلة لمجالات التغيير إذ يشير (فرج ، ، 91 (1) إلى "آن أحد القواعد الرئيسة في تصميم فقرات الاختبار شموله فقرات نشكل عينة ممثلة للمجال الذي

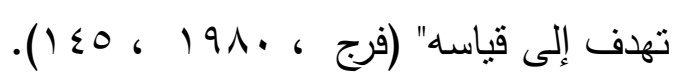

هـ. ملاءمة بدائل المقياس إذ لكل فقرة تدرج خماسي على وفق مقياس ليكرت (likert scale) وهذا يـوفر لـلأداة إمكانيـة توجيـهـ المجيـب إلـى اسـتجابات محـدة و تمكـن الباحثـان مـن مقارنــة

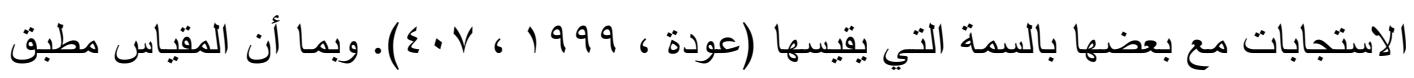
على عينة دن وزارة الإسكان و التعمير تطلب أجراء بعض التعديل والإضـافة عليه بما يناسب بهاب عينة البحث، وفي أدناه وصف للمعاملات العلمية التي أجريت لإمكانية استخدام المقياس في هذا البحث: r-r-1 الصدق الظاهري للمقياس 
ويقصد به "مناسبة الأداة للهدف الذي أعدت لقياسه" (الغريب ، 1910 ، ، ـ11). ويمكن

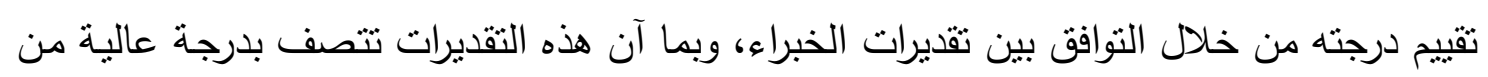

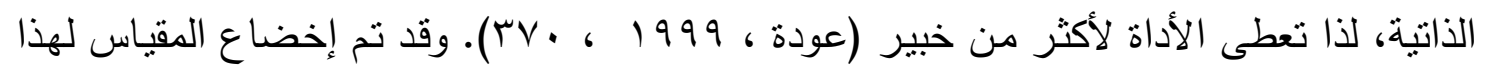

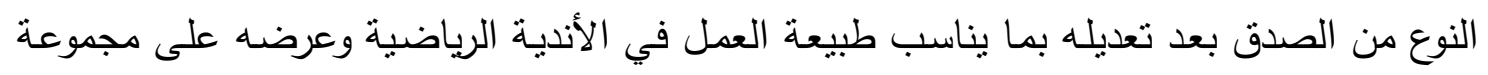

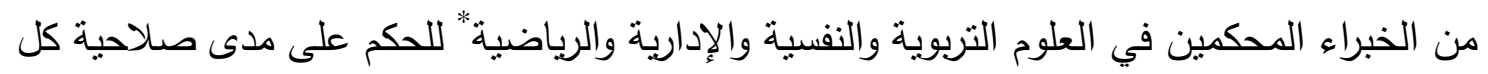

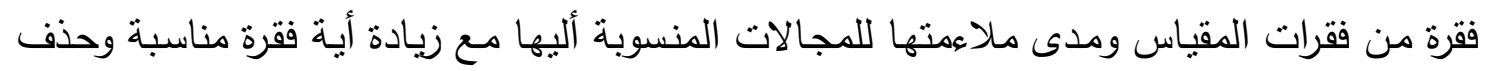

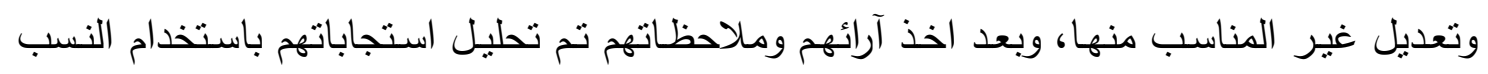

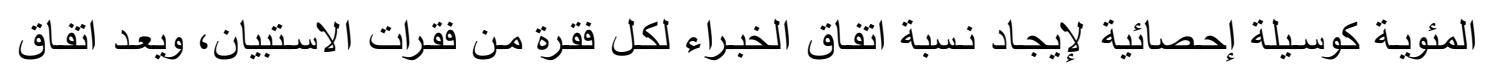

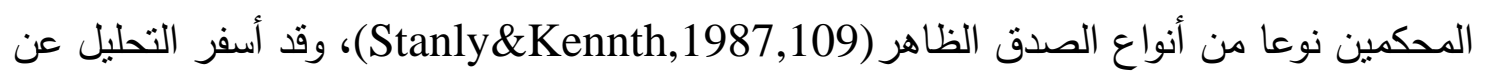

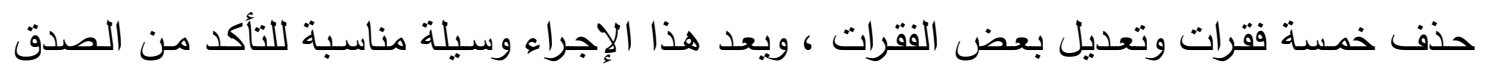

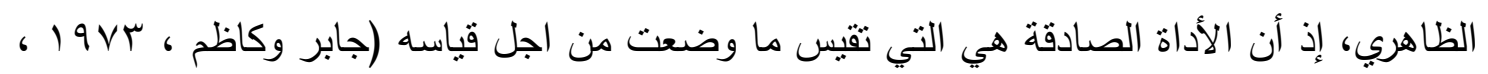

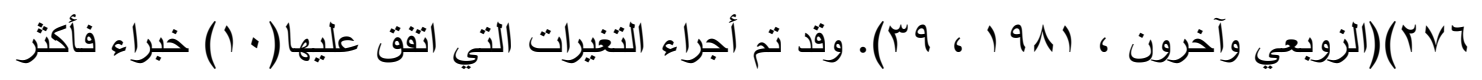

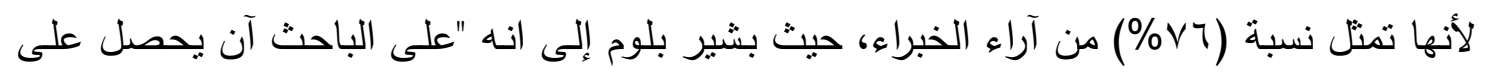

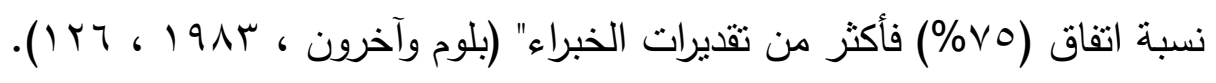

\section{r-r-r توزيع فقرات المقياس}

تم توزيع فقرات المقياس البالغة (به) فقرة بواقع خمسة مجالات لكي لايتاثر المجيب بنمط الفقرات الخاص بكل مجال من الدجالات.

ا. أ. أ.د عقيل الكاتب / كلية التربية الرياضية / جامعة بغداد.

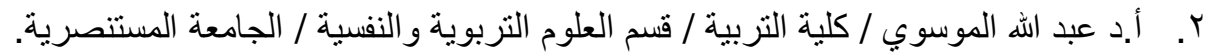

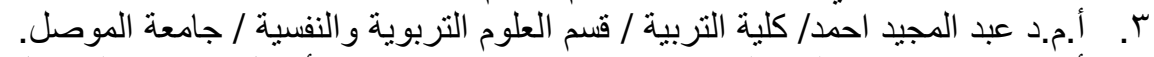

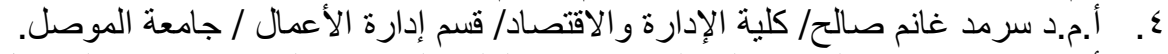

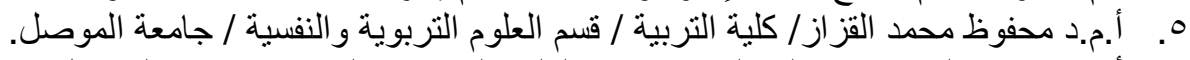

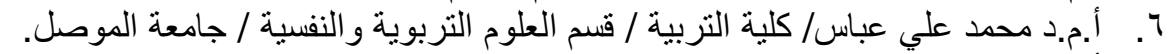

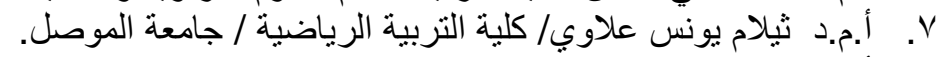

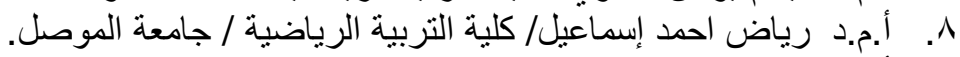

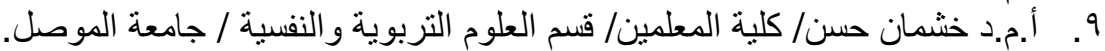

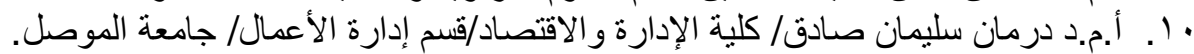

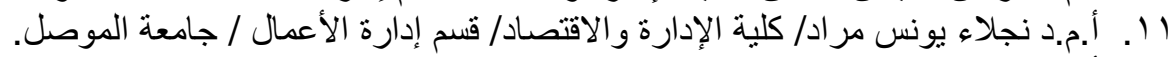

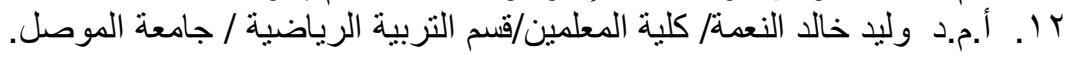




\section{r-r-r التجربة الاستطلاعية الأولية}

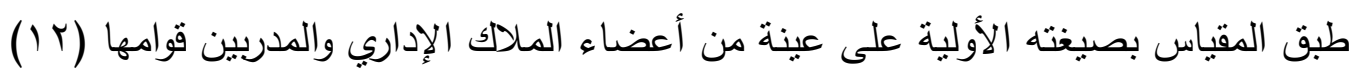

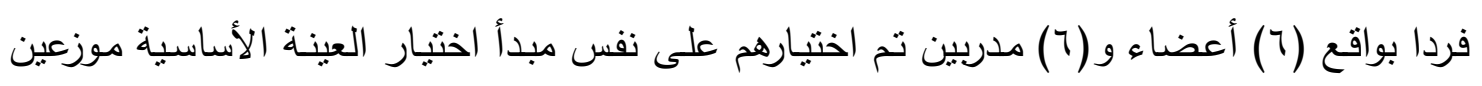

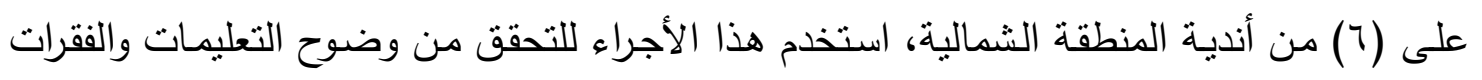

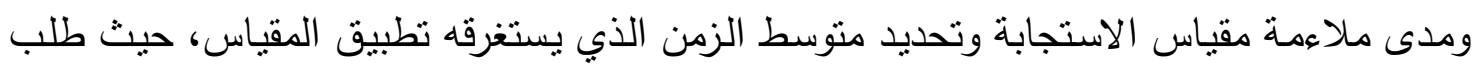

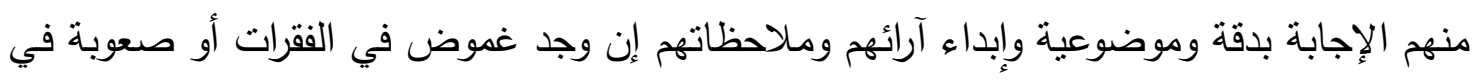

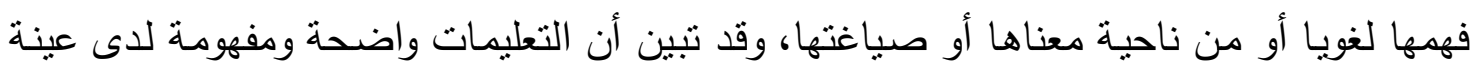

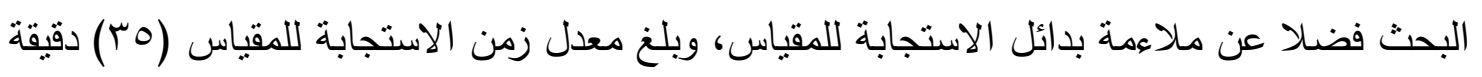

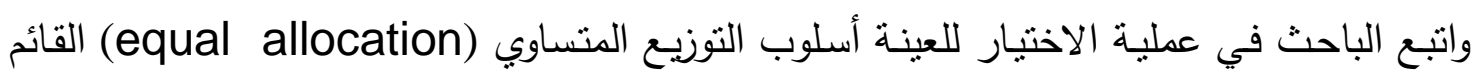

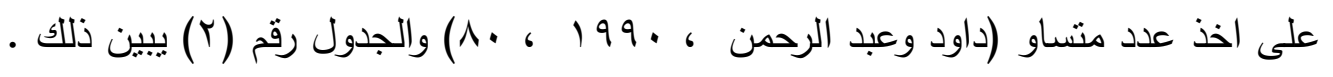

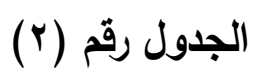
يبين أندية التجربة الاستطلاعية الأولى وأعداد الملاك الإداري والمدربين

\begin{tabular}{|c|c|c|c|c|}
\hline المجموع & مدرب & عضو أداري & الأندية & ت \\
\hline r & 1 & 1 & الثهيد سيروب & -1 \\
\hline r & 1 & 1 & تلعفر & $-r$ \\
\hline r & 1 & 1 & سنجار & r \\
\hline r & 1 & 1 & الفتوة & $-\varepsilon$ \\
\hline r & 1 & 1 & بيرس & -0 \\
\hline r & 1 & 1 & أكاد & -7 \\
\hline Ir & 7 & 7 & \multicolumn{2}{|c|}{ المجموع } \\
\hline
\end{tabular}

\section{r-r- צ تصحيح المقياس والمكم على درجة المستجيب :}

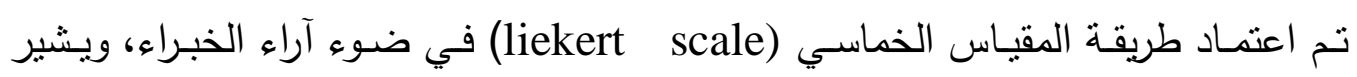

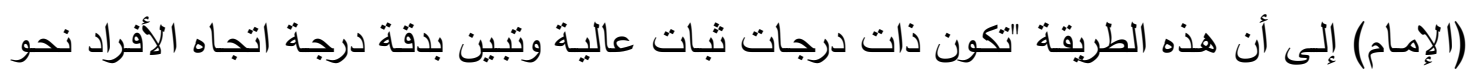

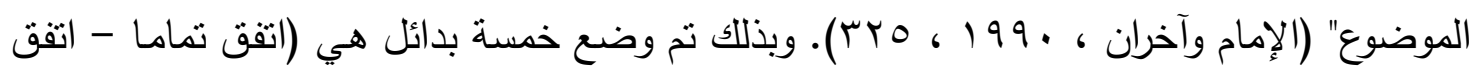

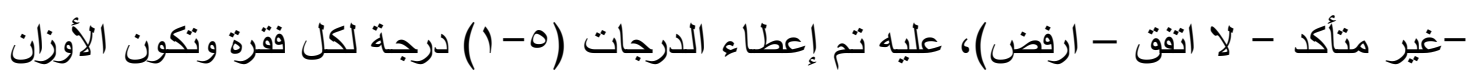

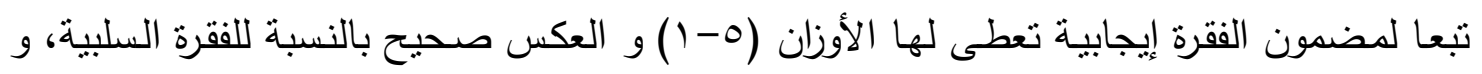


بذللك تكون أعلى درجة يحصل عليها المستجيب تساوي عدد الفقرات مضروبا في أعلى وزن وهو

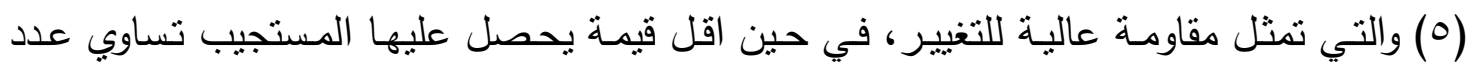

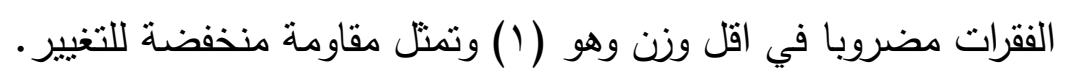

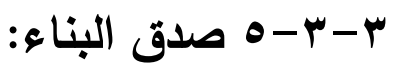

تم الكثف عن صدق البناء باستخدام طريقتين: الأولى - بإيجاد صدق المفردة عن طريق

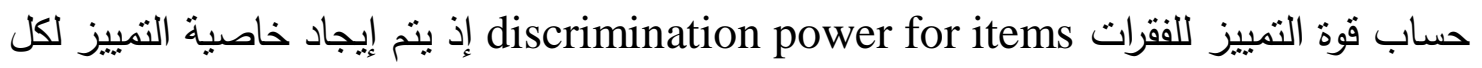

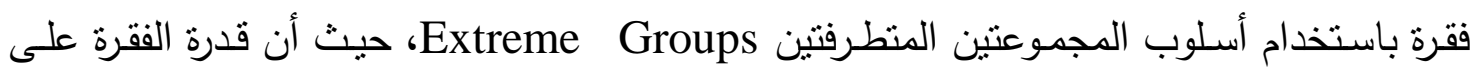

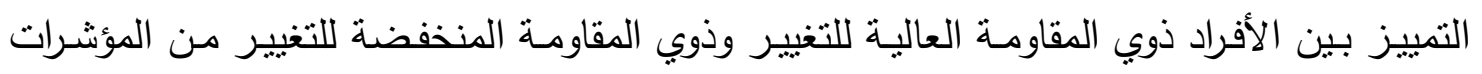

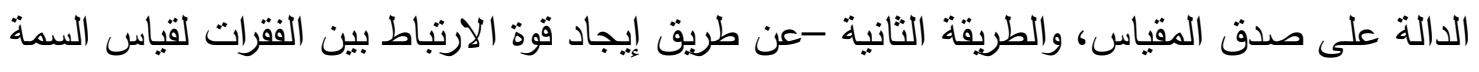

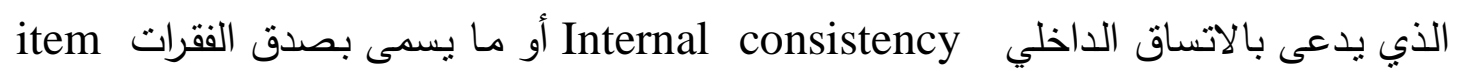
validity

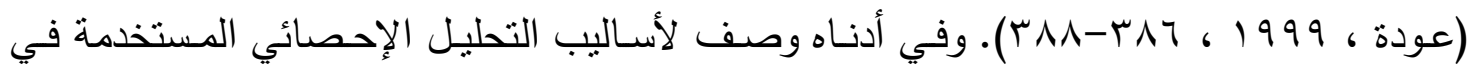
التحقق من صدق بناء مقياس مقاومة التغيير : أ. أسلوب المجموعتين المتطرفتين:

لاختبار قوة الفقرات حسب معامل تمييز الفقرات تم تحديد عينة التميز باختبار عينة عمدية

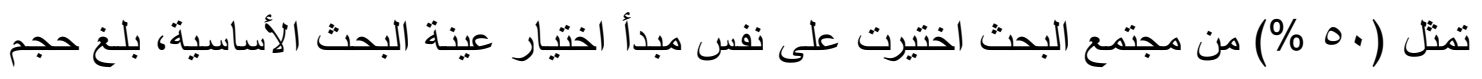

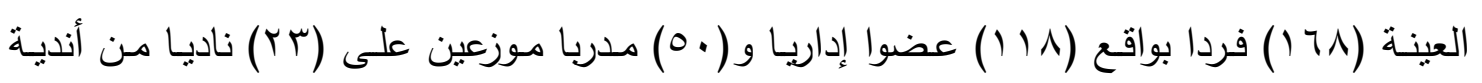

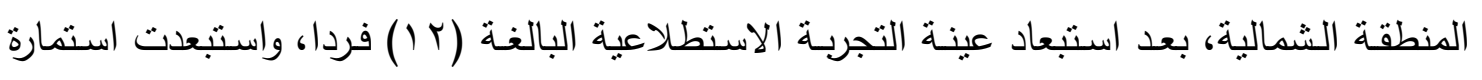

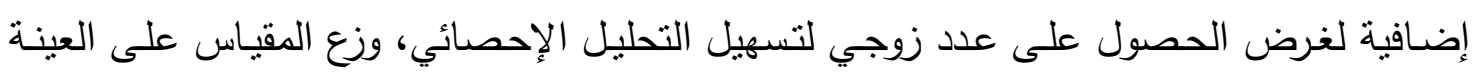
وتضمن شرحا على أهداف البحث وأهميته مع التأكيد على الإجابة عن جميع الفقرات وأهية الإجابة التهية

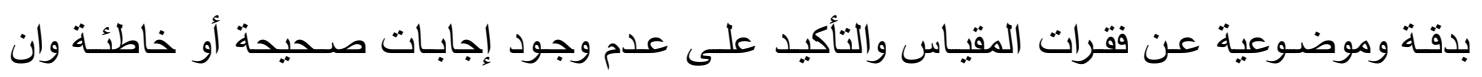

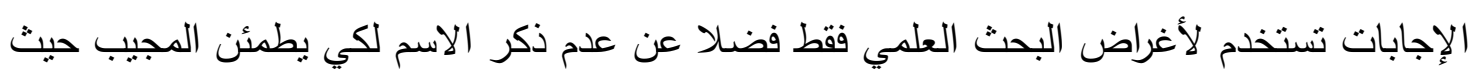

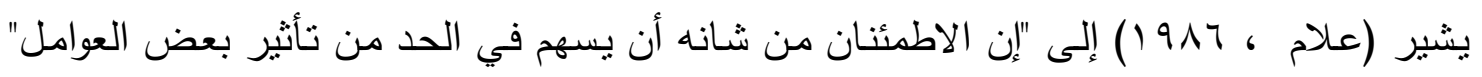

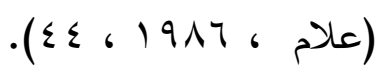

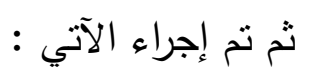

- نرتيب الدرجات تتازليا لكل فقرة من فقرات المقياس ولجميع الاستمارات. 
- تحديد حجم المجموعتين المنطرفتين العليا والدنيا بسحب نسبة ( (0 \%) من الدجموعة العليا

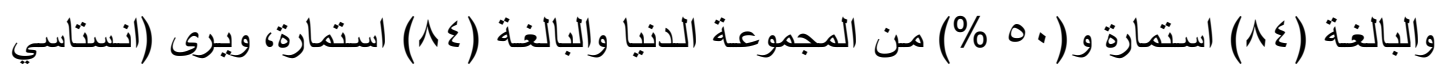

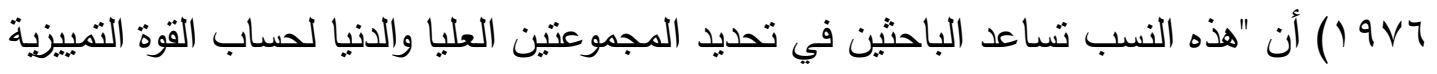
الخاصة بالفقرات" (Anastasi,1976,208). تم حساب القوة التمييزية للفقرات باستخدام الاختبار

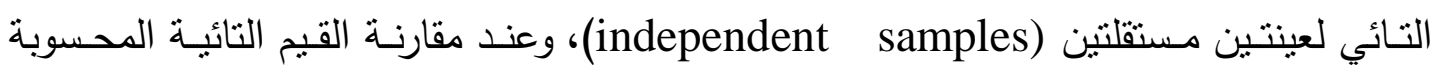

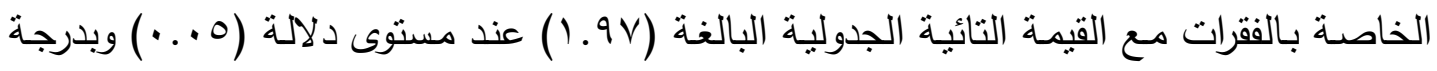

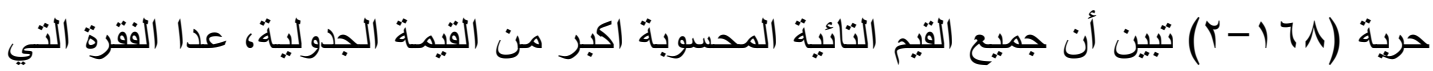

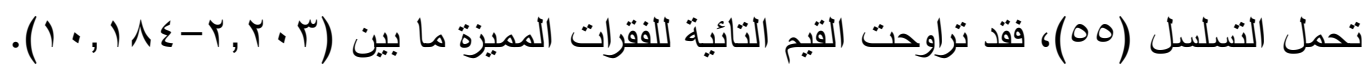
ب. أسلوب معامل الاتساق الاخلي: بعد استبعاد الفقرة غير المميزة تم إيجاد معامل ارتباط درجة كل فقرة بالدرجة الكلية لنفس عينة التمييز البالغة (141) فردا، وقد تم حساب معاملات ارتباط درجة كل فقرة بالدرجة الكلية

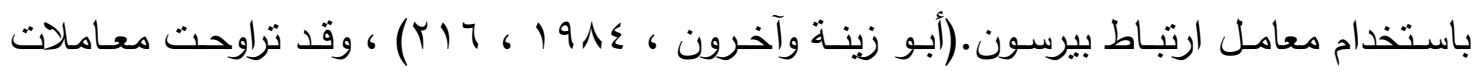

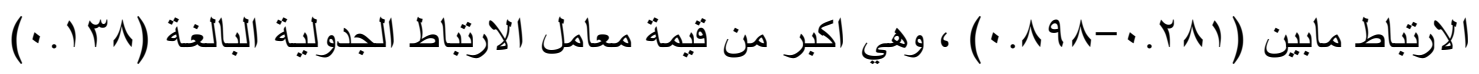

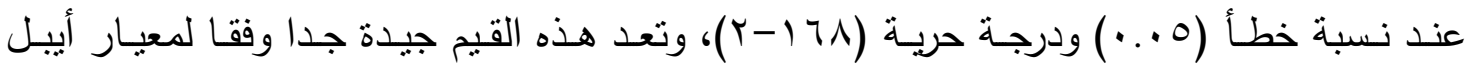

.(Ebel,1972,267)

r-r

لغرض الحصول على الثبات استخدت الطرائق التالية:

أ. طريقة التجزئة النصفية :

تم تصحيح (171) استمارة شملت عينة التمييز بعد حذف الفقرات غير المميزة ثم قسمت إلى نصفين : النصف الأول بمثل الفقرات ذات النسلسلات الفردية والنصف الثاني يمثل الفقرات ذات النسلسلات الزوجية بحيث أصبح لكل فرد درجتان فردية وزوجية، وتم إيجاد معامل الثبات من خلال

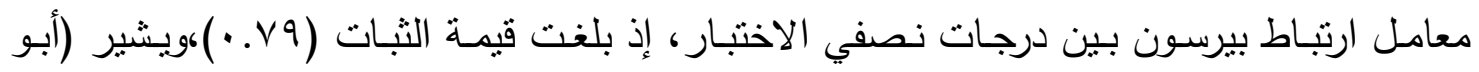
حطب وآخران ب99 (1) إلى "أن الارتباط بين درجات كل من نصفي الاختبار يعتبر بمثابة الاتساق

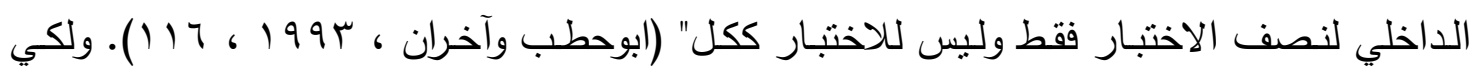

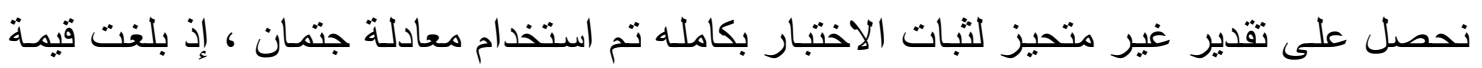

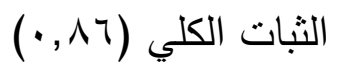

rTV 


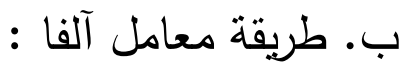
بلغت قيمة معامل ألفا (Y9 , ·)، ويعد هذا الثبات عاليا مقارنة بقيم معامل آلفا الواردة في

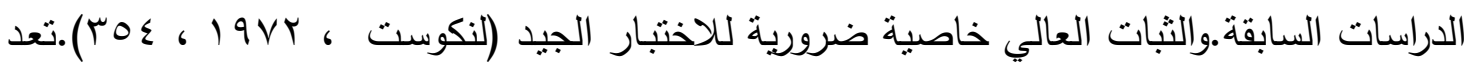

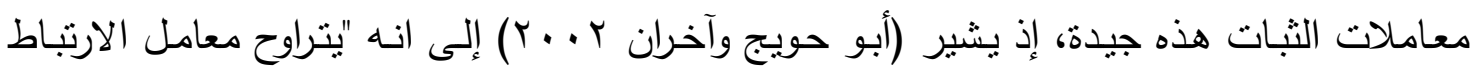

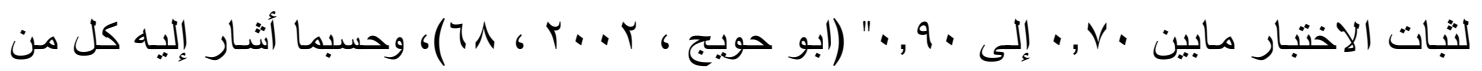
g( 1 r. ، 1919،

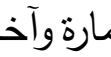

$$
\begin{aligned}
& \text { (عودة والخليلي ، ... T ، 7 § 1). } \\
& \text { r-؛ تطبيق أداتي البحث : }
\end{aligned}
$$

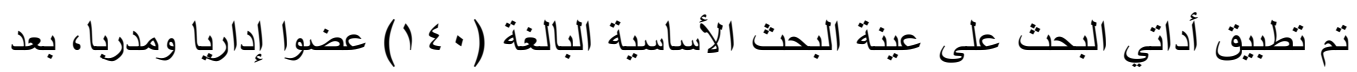

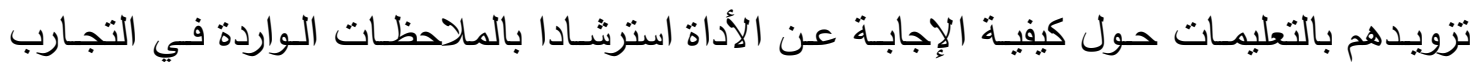

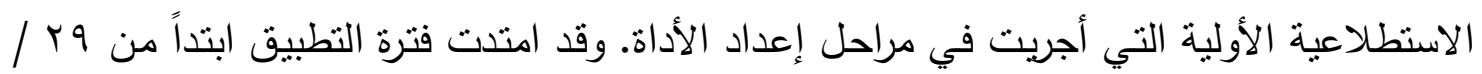

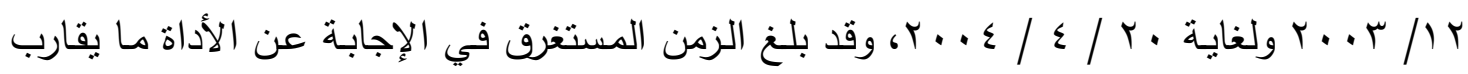

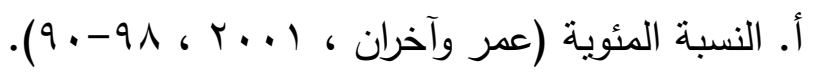

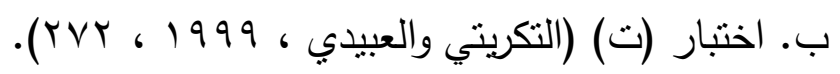

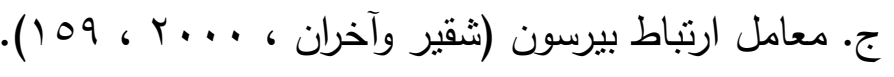

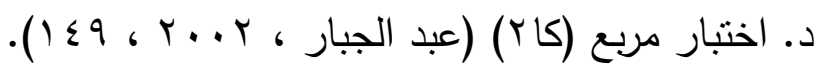
هـ-المنوسط الفرضي (علاوي ، 1991 ، ، ـ (1). وتم استخدام الحاسوب الآلي بنظام

\section{ع - عرض النتائج ومناقشتها}

سيتم عرض النتائج ومناقثتها وفقا لأهداف البحث والمستلة من اطروحة الدكتوراه وكالاتي :

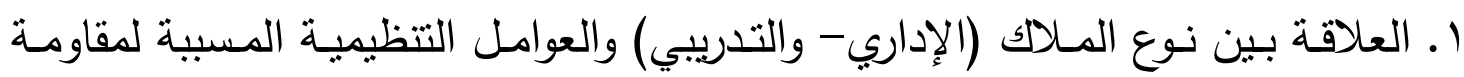
التغيير :

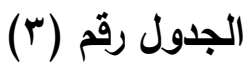

يبين النسبة المئوية وكاب لإجابات عينتي البحث في العوامل التنظيمية المسببة لمقاومة التغيير 


\begin{tabular}{|c|c|c|c|c|c|c|}
\hline \multirow{3}{*}{ كاr } & \multicolumn{2}{|c|}{ الملاكك التدريبي } & \multicolumn{2}{|c|}{ الملاك الإداري } & \multirow{3}{*}{ المثرضط } & \multirow{3}{*}{ العوامل التنظيمية } \\
\hline & \multirow{2}{*}{$\%$} & العدد العد & \multirow{2}{*}{$\%$} & العدد العد & & \\
\hline & & $\varepsilon 1$ & & 99 & & \\
\hline $.1 \mathrm{r}$ & $\% 71$ & ro & $\% 70$ & $7 \varepsilon$ & 7 & احتمال بقاء نظام المكافآت \\
\hline ( & \%тr & $r y$ & $\% \circ \wedge$ & ov & 7 & التنافس والصراع \\
\hline 1.04 & $\%$ \% & 17 & $\% 01$ & 0. & r & التكاليف غير المستغلة \\
\hline .71 & $\% 01$ & $r_{1}$ & $\% \leq r$ & $\varepsilon r$ & 7 & المناخ التتظيمي \\
\hline r.VA & $\% \circ r$ & rr & $\%$ \% & r & 7 & ضعف اختيار الطرائق المناسبة \\
\hline 1.9 & $\% \leqslant 1$ & iv & \%rr & 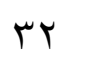 & 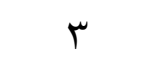 & جمود الهيكل التنظيمي \\
\hline$\vee .9$ & $\%$ or & Yr & $\%$ \% & rq & r & الفشل محاولات التغيير السابقة \\
\hline
\end{tabular}

من ملاحظة الجدول رقم (r) نجد ماياتي : احتمال بقاء نظام المكافآت :

جاء هذا العامل بالترتيب الأول بالنسبة إلى أعضاء المـلاك الإداري، إذ بلغت نسبة الذين يعارضـون التغيير في حالة بقاء نظام المكافآت (07\%)، وبلغت نسبة أعضاء المـلاك التدريبي (17\%)، ويمثل هذا العامل الترنيب الثاني بالنسبة إليهم.وقد يكون السبب هو أنهم اعتادوا على نمط معين من العمل ونظام المكفاءات وتكيفوا مع هذا النظام وأسلوب العمل ويجدون أن التغيير قد يقلق توازنهم دون حصول تحسين في أحوالهم المعاثية، وهنا بشير (داغر وصالح ، .. . ب) إلى أن "الأفراد يقاومون التغيير عادة عندما لا يلمسون أي تغيير إيجابي في أحوالهم الماديـة أو المعنويـة نتيجة تطبيق التغيير ، فلماذا يعمل الفرد ساعات أطول وعلى وفق أسـاليب عمل جديدة دون ان يحصل مقابل ذلك على أي تحسين في وضعه" (داغر وصالح ، . . . . ، 007). التنافس والصراع :

حصل هذا العامل على الترتيب الثاني لدى أعضاء الملاك الإداري إذ بلغت نسبة الذين

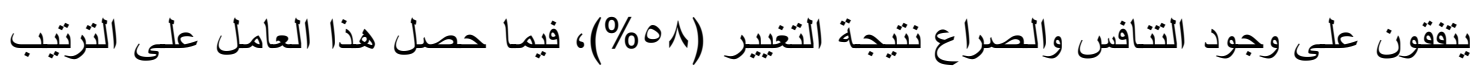
الأول بالنسبة إلى المدربين بنسبة (ז7\%).ولا ينظر إلى هذه النتيجة بالسلبية، حيث يفترض وجود حد أدنى من الصراع في النادي الرباضي الذي يزبد من المنافسة لكي لا يبقى النادي جامدا وغير مستجيب للتطورات الحاصلة في الأندية الأخرى، إذ يشير (أبو قحف ال . . ب) إلى أن "المنافسة تستخدم كحافز للحث على السلوك المرغوب حيث يمكن أن بتتافس الفرد مع ذاته ومع زملاءه أو 
باعتباره أحد أفراد جماعـة تتتافس مـع جماعـة عمل أخرى، فالمنافسة الذاتيـة أو الثخصية عندما

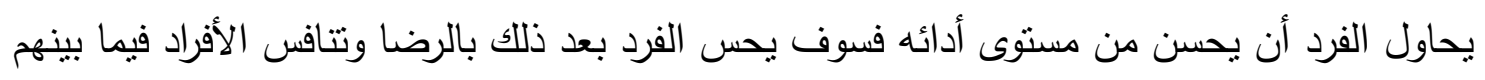

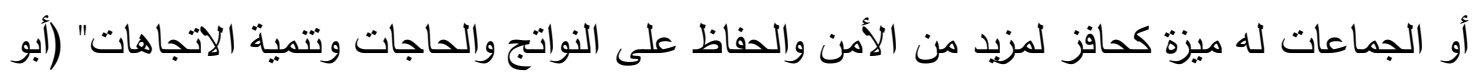

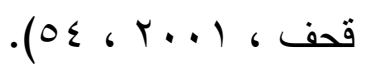
التكاليف غير المستغلة : حصل هذا العامل على الترتيب الثالث بالنسبة إلى أعضاء الملالك الإداري فقد بلغت نسبة

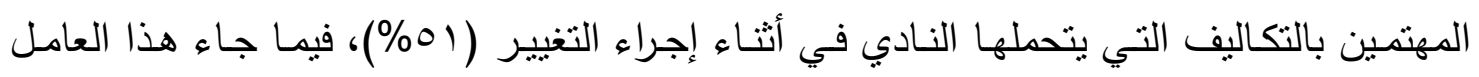
بالترنيب الأخير عند المدربين بنسبة (9٪\%).ولعل السبب في ارتقاع نسبة أعضاء الملاك الإداري

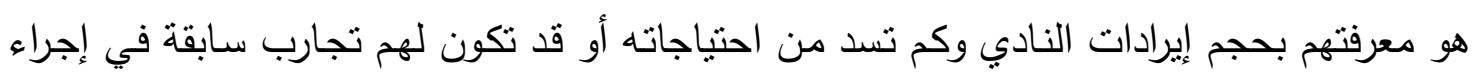

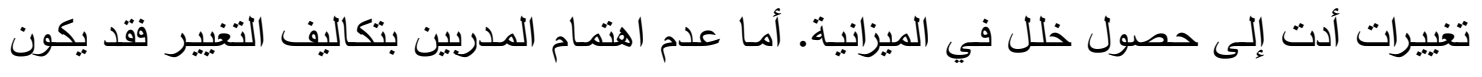

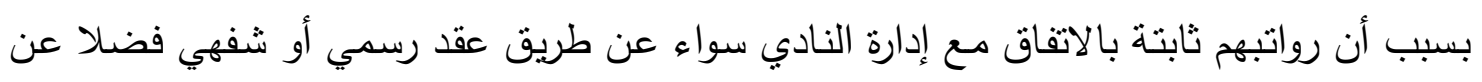

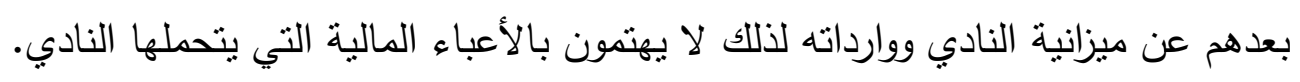

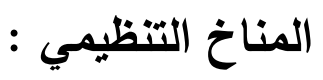

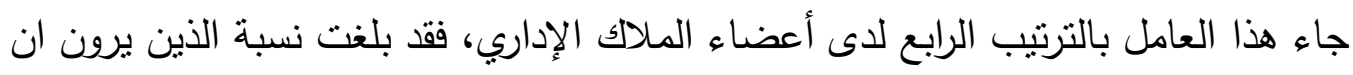

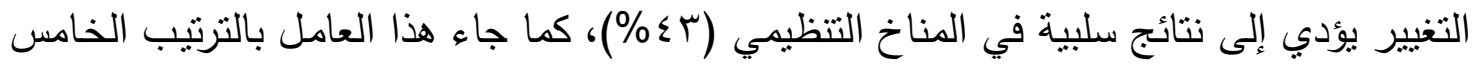

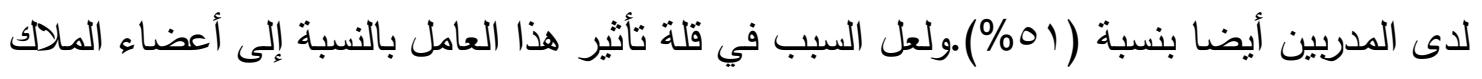

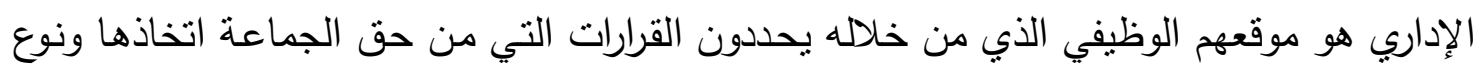

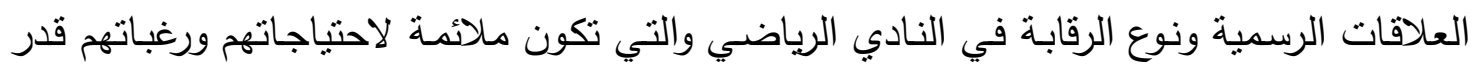

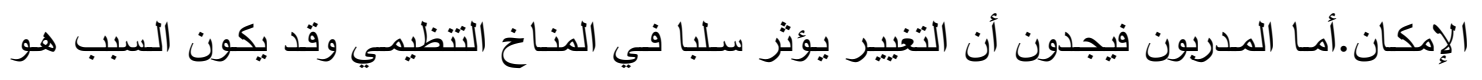

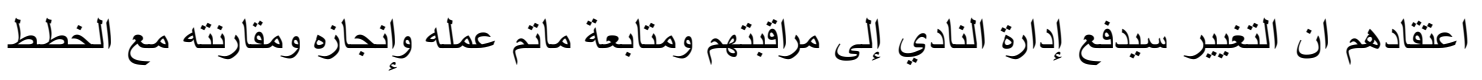

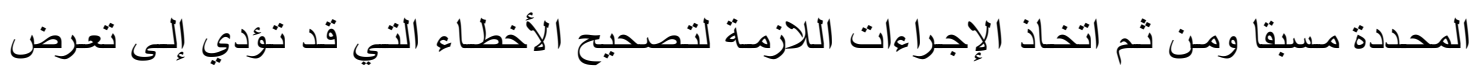

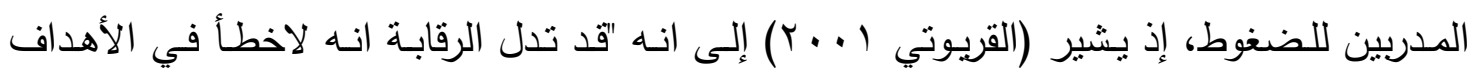

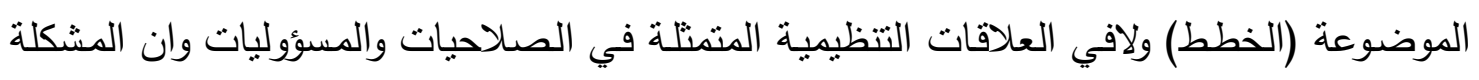

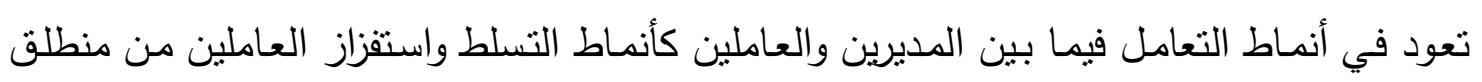

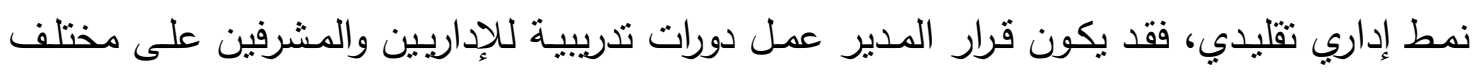

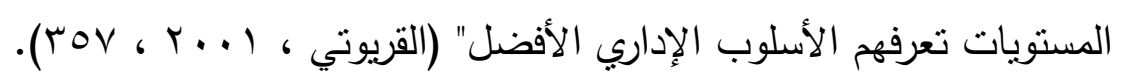
ضعف اختيار الطرائق المناسبة في إذخال التغيير :

rT. 
حصل هذا العامل على الترتيب الخامس لدى أعضاء الملاك الإداري فقد بلغت نسبة الذين يؤيدون ضعف اختيار الطرائق المناسبة في إدخال التغيير (^^\%)، في حين حصل هذا العامل على الترتيب الثالث بالنسبة إلى المدربين بنسبة (ب\%\%).ولعل السبب في انخفاض نسبة أعضاء المالك الإداري هو التعاون فيما بينهم لتقارب مصالحهم إذ يشير (ريجو 999 (1) إلى انه "قد يساعد الأعضاء بعضهم البعض على أساس تبادل المنفعة، كذلك لان تحقيق أهداف المؤسسة سيعود لكل

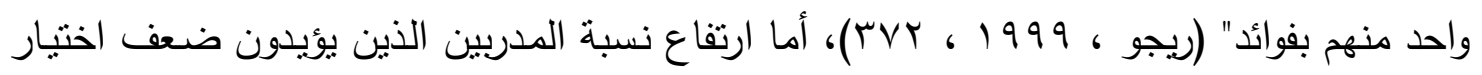
الطرائق المناسبة في إدخال التغيير فقد يكون بسبب خبراتهم السابقة فيما يخص التغيير الذي غالبا مـا يكون غير مدعوم بنظـام الحوافز كما يدل على عدم التعاون بين المدربين وأعضاء المـلاك الإداري وعلى عدم رضا المدربين على أساليب الإدارة وهنا يشير (كلالدة ل99 1 ) إلى انه "إذا أراد القائد ديمومـة متواصلة من العمل كفريق وتسخير الطاقات والنشاطات كافة لابد من وجود نظام حوافز Motivation System Sy لا يرتكز فقط على الحوافز الماديـة الفرديـة بـل بمتـد إلى حوافز جماعية والى حوافز معنوبة وان تلبي هذه الحوافز بمختلف أثكالها الحاجات وإثباعها لدى العاملين مما يؤدي إلى عدم شعور الفرد بالقلق وتعاونـه في العمل وشعوره بالانتماء إلى التنظيم الذي يعمل

$$
\text { جيه" (كلالدة ، لو 199 1 ، } 9 \text { (1). }
$$

حصل هذا العامل على الترتيب السادس لدى أعضاء الملاك الإداري فقد بلغت نسبة الذين يرون جمود الهيكل التنظيمي الذي يتميز بالروتين والتفصيلات الزائدة التي تؤدي إلى معارضتهم للتغيير(r\%\%)، فيما حصل هذا العامل على الترتيب السادس لدى المدربين بنسبة (1 (1\%)، وقد يكون السبب في انخفاض هذه النسبة هو قلة تعقيدات الهيكل التتظيمي للنادي الرياضسي أو أن تفصيلات الهيكل التتظيمي أصبحت جزءا من عملهم وتكيفوا معها من خلال ممارستهم اليوميـة لها أو بسبب التصميم الجيد للهيكل التظظيمي، إذ يشير (حريم ب . . r) إلى أن "الطريقة التي يتم تعميم الأعمال والتخصيص وتحديد الأدوار وتكوين الوحدات التنظيمية وتفويض السلطة كلها تؤثر إيجابيا أو سلبا على سلوك الأفراد والجماعات في المنظمات" (حريم ، ب . . ب ، 7 ـ ( ). فشل المنظمة في محاولات التغييز السابقة : جاء هذا العامل بالترتيب الأخير لدى أعضاء المـلاك الإداري والتدريبي فقد بلغت نسبة

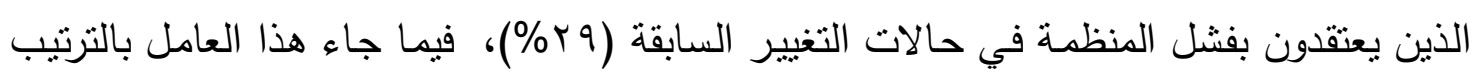
الثالث لدى المدربين بنسبة (\%ه\%).وهذا يعني أن أعضاء المـلك الإداري لا يعترفون بالفشل في هي

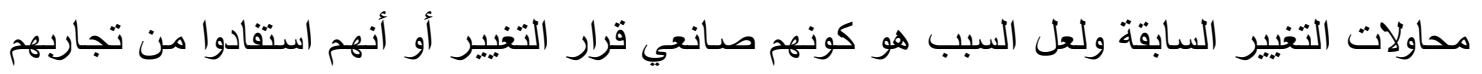


السابقة وهم على استعداد لتلافي المشاكل التي كانت سببا في الدحاولات السابقة. أما المدربون

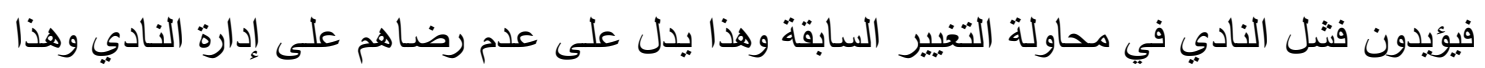
ما ذهب إليه الباحث في العامل الخامس من العوامل التتظيمية.

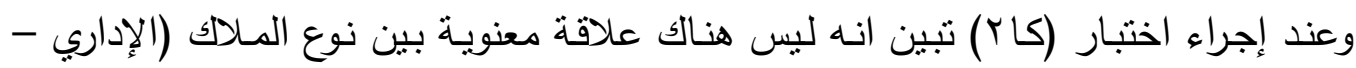

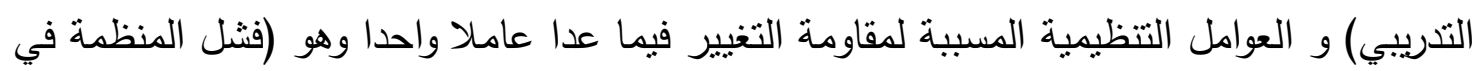

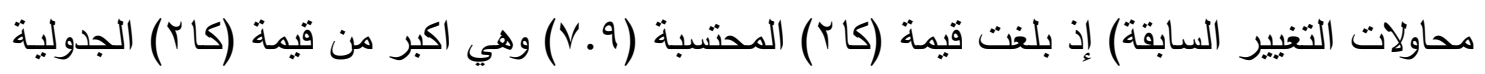

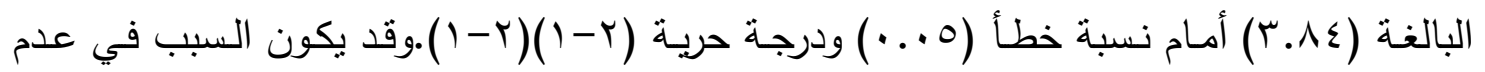

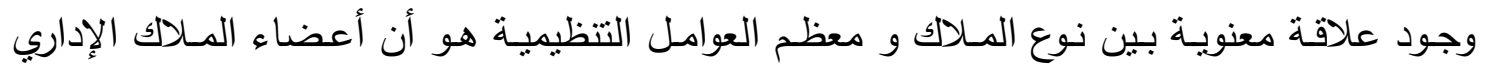

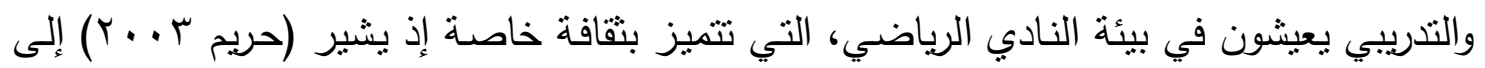

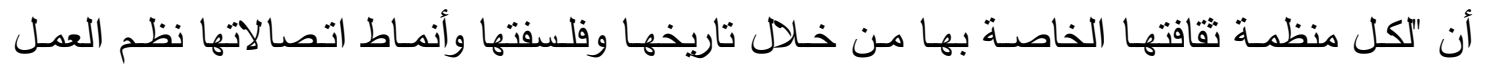

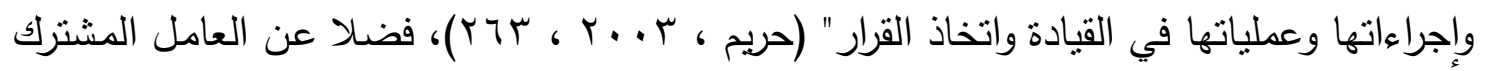

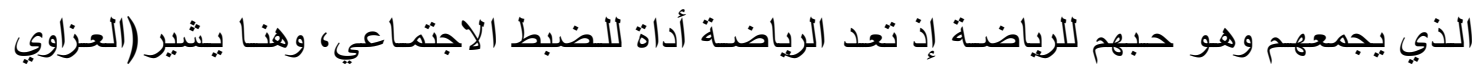

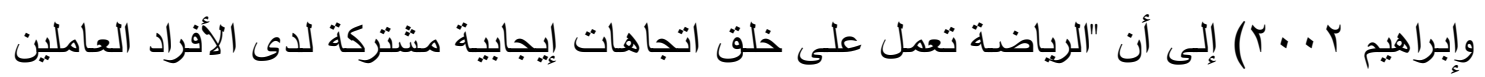

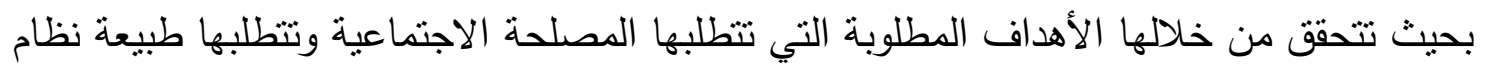

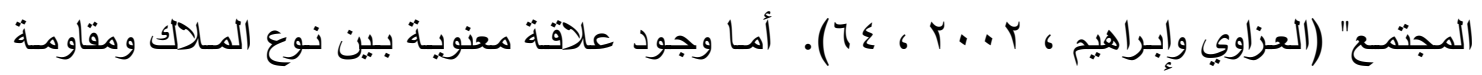

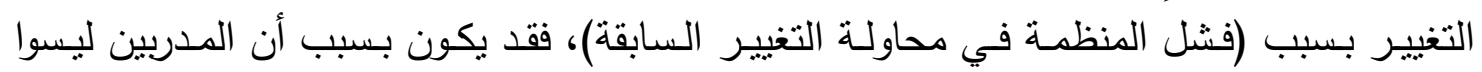

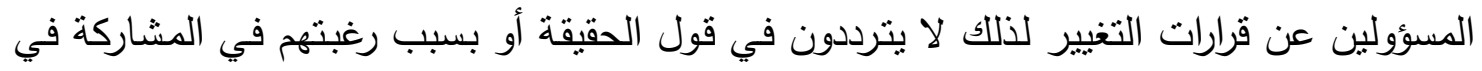

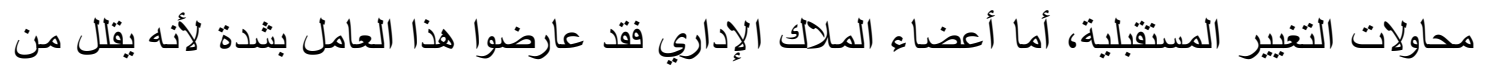
شأن كفايتهم في الإدارة.

r.العلاقة بين نـوع المـلاك (الإداري -التـدريبي) والعوامـل الفرديـة المسبية لمقاومـة التغيير. - التعان

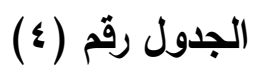

يبين النسبة المئوية وكا ب لإجابات عينتي البحث في العوامل الفردية المسببة لمقاومة التغيير

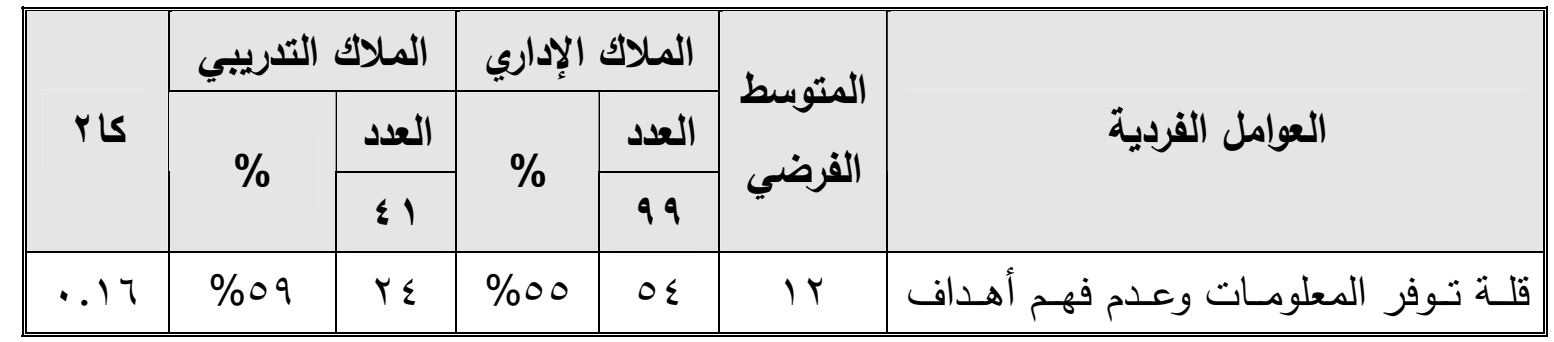

rtr 


\begin{tabular}{|c|c|c|c|c|c|c|}
\hline & & & & & & 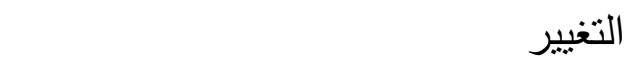 \\
\hline$\cdot, \cdot 1$ & $\% \leqslant 7$ & 19 & $\% \leqslant V$ & $\leqslant V$ & 7 & صعوبة تغيير العادات \\
\hline 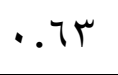 & $\% 01$ & Yl & $\% \leqslant r$ & $\varepsilon r$ & 7 & تضارب الأهداف الفردية والتنظيمية \\
\hline 1.79 & $\% \circ \varepsilon$ & rt & $\%$ ऽ & 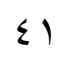 & r & صعوبة التحلل من قواعد سلوك الجماعة \\
\hline $1 . r \varepsilon$ & $\% 01$ & $r_{1}$ & $\% \varepsilon$. & $\varepsilon$. & $r$ & تهديد التغيير للمصالح الاجتماعية السائدة \\
\hline صفر & $\%$ rq & 17 & $\%$ \% & rq & 7 & التكيف والاندماج \\
\hline r.o & $\% 0 \leq$ & rt & $\%$ & r & 7 & الخوف من فقدان الوظيفة \\
\hline .10 & $\%$ YV & 11 & $\%$ r. & $r$. & 7 & القصور في معرفة الحاجة إلى التغيير \\
\hline
\end{tabular}

كاr

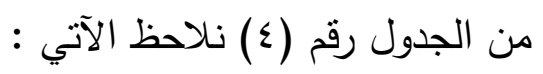

\section{قالة توفر المعلومات وعدم فهم أهداف التغيير :}

حصل هذا العامل على الترتيب الأول لدى أعضاء المـلاك الإداري والتدريبي، فقد بلغت نسبة الذين يقـاومون التغيير بسبب قلـة توفر المعلومـات وعدم فهم أهداف التغيير (00\%) مـن أعضاء الملاك الإداري و (ه9\%) من أعضاء المالاك التدريبي.وهذا يدل على أن أعضاء الملاك الإداري والتذربيجي يتفقون على أن عدم فهم أهداف التغيير يؤدي إلى مقاومته وهذه نتيجة طبيعية لان الإنسان عدو لمـا يجهل كما يقول العرب، فأن أي جهد تغييري يصطدم في كثير من الأحيان

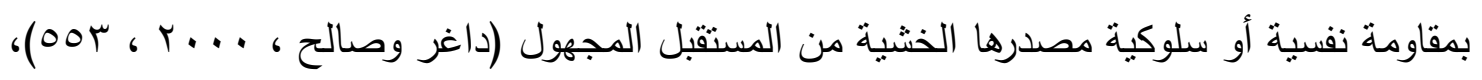
ويشير (الثماع وحمود . . . إلى أن "سوء أو حسن فهم أهداف التغيير من شأنه أن يسهم في تعميق أو تقليص حدة المقاومـة لـدى الأفراد سـيما إذا أدرك الأفراد أو الجماعـات أهميـة التغييـر

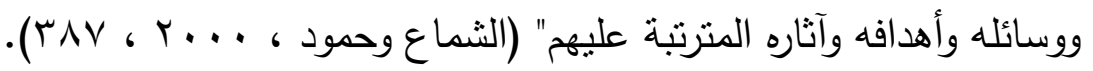

\section{صعوية تغييز العادات :}

جاء هذا العامل بالتزتيب الثاني لدى أعضاء الملاك الإداري، اذ بلغت نسبة الذين يجدون صعوبة في تغيير العادات (V ٪\%)، فيما جاء هذا العامل بالترتيب السادس لدى المدربين بنسبة

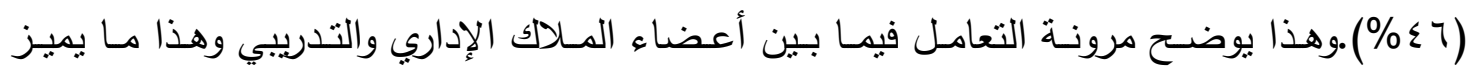
الجماعات الصغيرة، وهنا يشير (عويس والهلالي 999 (1) إلى أن "هذه الجماعات تتميز بالعلاقات

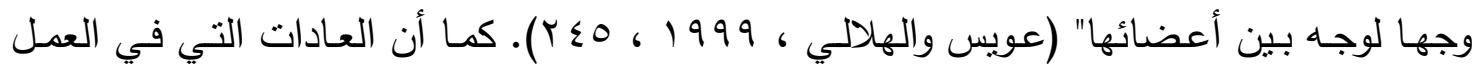
تعنبر أمرا اختياربا وغير ملزما، ويشير (الرشدان 999 (1) إلى أن "مثل هذه العادات أمر اختياري 
وتفضيلي وغير ملزم لذا من الممكن تغييرها، أما العادات الملزمة فختلفة منها-العرف والمحرمات)"

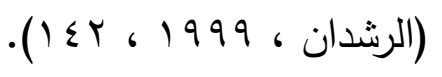

\section{تضارب الأهداف الفردية والجماعية :}

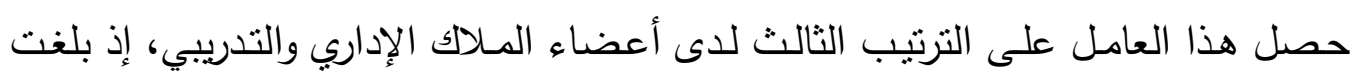

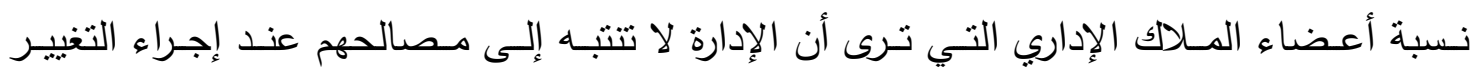

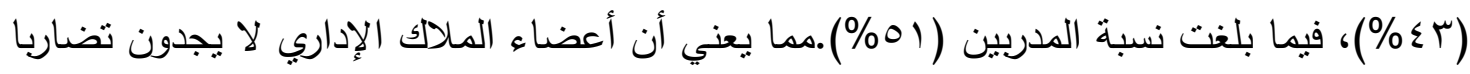

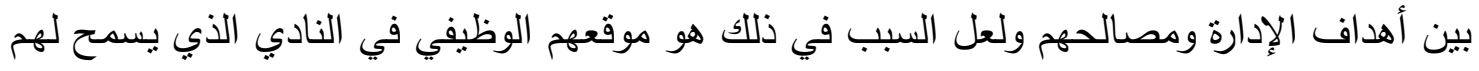

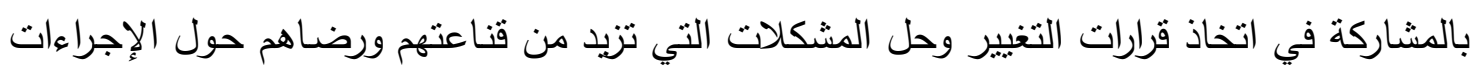

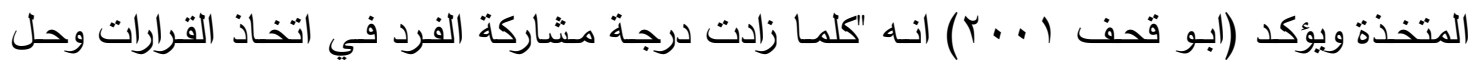

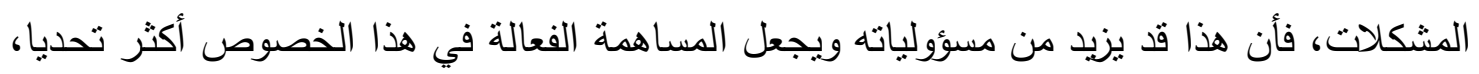

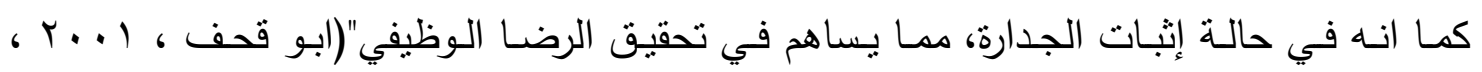

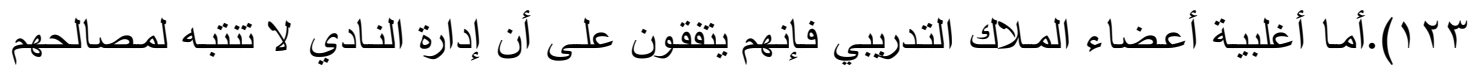
الثخصية مما يوحي بوجود فجوة إدراكية سلبية فيما يخص مصالح المدربين.

\section{صعوية التحلل من قواعد سلوك الجماعة :}

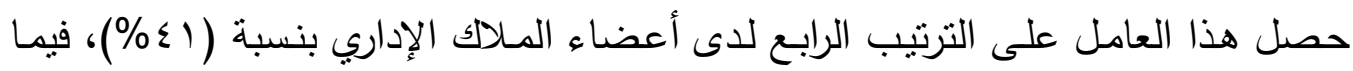

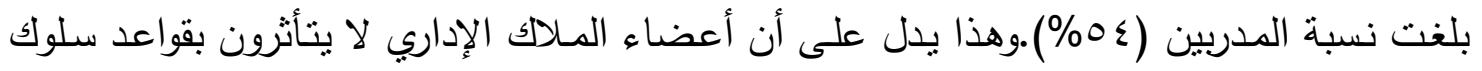

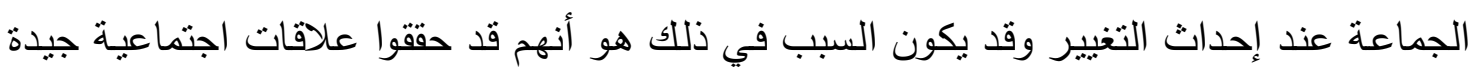

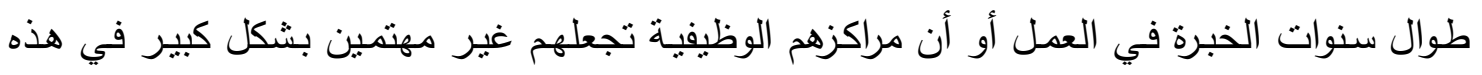

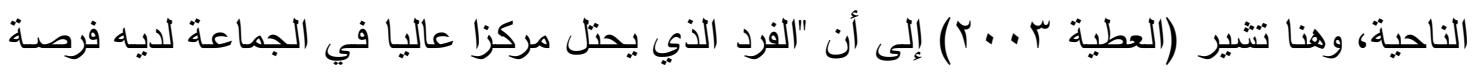

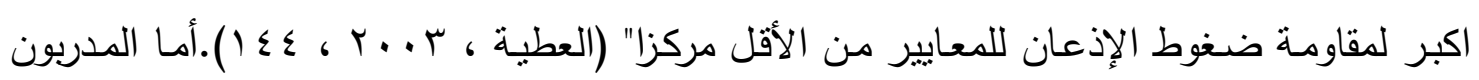

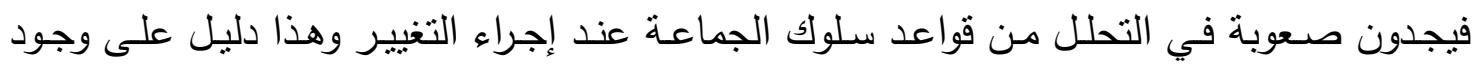

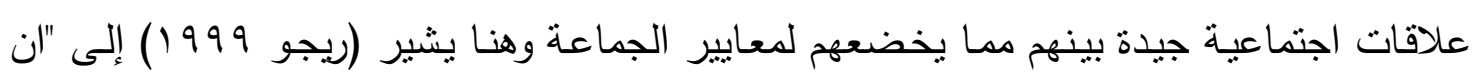

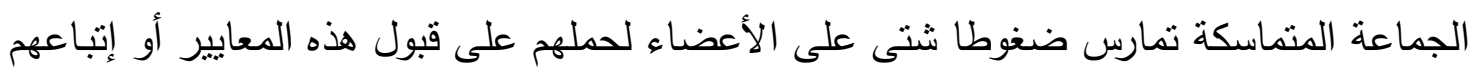

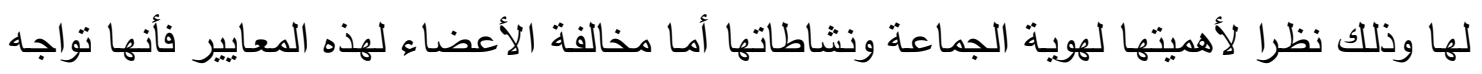

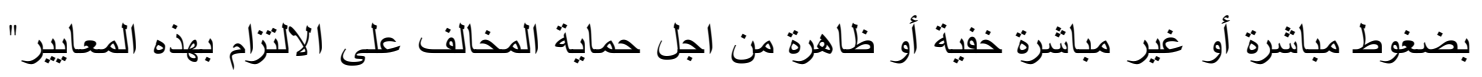

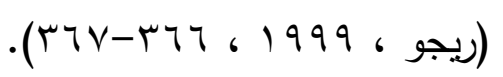

تهايد التغيير للمصالح الاجتماعية السائدة :

צ 
حصل هذا العامل على الترتيب الخامس لاى أعضاء الملاك الإداري، إذ بلغت نسبة الذين يجدون في التغيير تهديدا للمصالح الاجتماعيـة السائدة ( • ع\%)، فيمـا حصل هذا العامل على الترتيب الثالث لدى المدربين بنسبة (1\%).وتعكس هذه النسبة عدم اهنمام أعضاء الملاك الإداري بالمصالح الاجتماعية السائدة عند إجراء التغيير، وقد يكون السب هو موقعهم الوظيفي الذي يعطيهم دعما اجتماعيا وتؤكد هذه النتيجة ما ذهب إلبه الباحث في العامل السابق.أما الاهتمام المتزايد من قبل أعضاء الملاك التدريبي بالمصالح الاجتماعية عند إجراء تغييرات في النادي الرياضي فقد يكون السبب أنهم لم يحققوا الإشباع الكافي لحاجاتهم.

التكيف والاندماج :

جاء هذا العامل بالترتيب السادس لدى أعضاء الملاكى الإداري فقد بلغت نسبة الذين يجدون صعوبة في التكيف والاندماج (qץ\%)، فيما جاء هذا العامل بالترتيب السابع لدى المدربين بنسبة (q (\%).وهذا يدل على قابليتهم الجيدة على التكيف والاندماج في حالة تغيير الوضع الحالي، وقد يعود السبب في ذلك إلى التحولات التي مـر بها مجتمعنـا إذ أن الحـروب المتتاليـة والحصـار الاقتصادي دفعت الأنديـة الرياضية إلى العيش تحت وطـأة الأزمـات، ممـا اضطرها إلى تطوير قابليتها بمـا يتتاسـ مـع الأوضـاع المتغيرة للحفاظ على بقائها وتوازنها من جهة وتلبيـة متطلبـات مناخها التنظيمي من جهة أخرى، ولما كانت متطلبات مناخها التتظيمي خاصة فيما بتصل بالأفراد

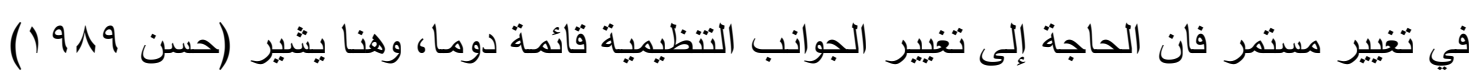

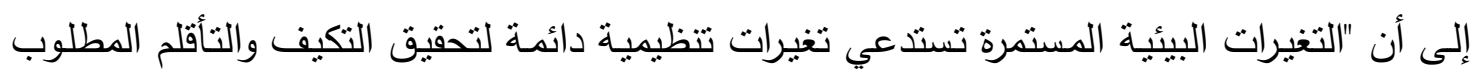
للبيئة بالمقابل تزداد الحاجة إلى تحقيق الاستقرار التنظيمي سواء في النشاطات والوظائف أو في الأفراد والعلاقات التنظيمية وذلك منعا للإرباك واختلال توازنها".

(Y^^ ، 1919 ، حسن)

\section{الخوف من فقدان الوظيفة :}

حصل هذا العامل على الترتيب السابع لدى أعضاء المـلاك الإداري بنسبة(بr\%) فيما حصل على الترتيب الثاني لدى أعضاء الملاك التدريبي بنسبة(؛ \%\%). وهذا يثنير إلى أن أعضاء الملاك الإداري لا يتققون مع تأثير التغيير في مركزهم الوظيفي وهذا يعكس مدى ثقتهم بأنفسهم وبعمهم ولعل السبب في ذلك أسلوب اختيار الأعضاء في النادي الرياضي القائم على الانتخاب الأمر الذي يعمل على زيادة ثقة الأعضاء بأنفسهم ومن خلال خبرتهم

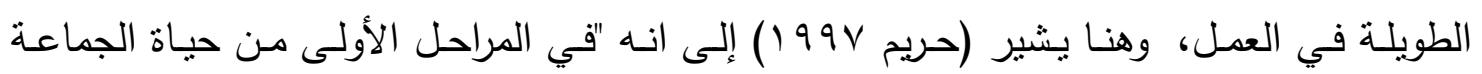




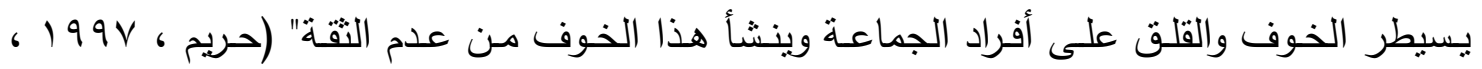
19 1).أما أعضاء الملالك التدريبي فيجدون أن التغيير يهدد مركزهم الوظيفي ولعل السبب في ذلك فئل

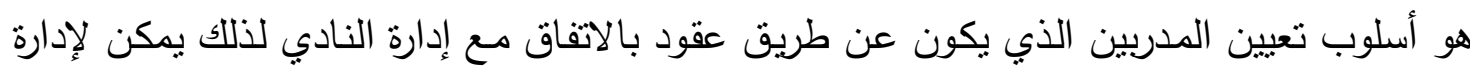

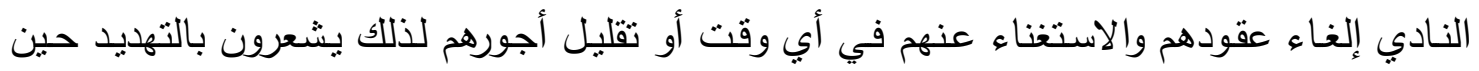
تطرح فكرة التغيير، وقد يكون الخوف نابعا من المزايا التي تتمتع بها الوظيفة التي يمارسونها.

\section{القصور في معرفة الحاجة إلى التغيير :}

جاء هذا العامل بالترتيب الأخير بالنسبة إلى العينة، فقد بلغت نسبة أعضاء الملاك الإداري

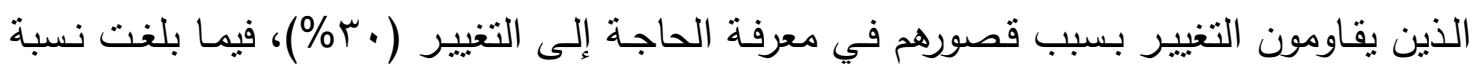

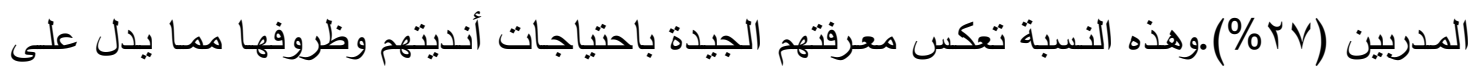
إدراكهم الجيد فضلا عن المعرفة الجيدة بظروف النادي.

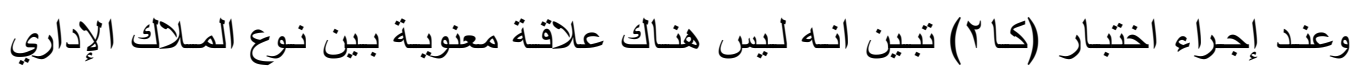

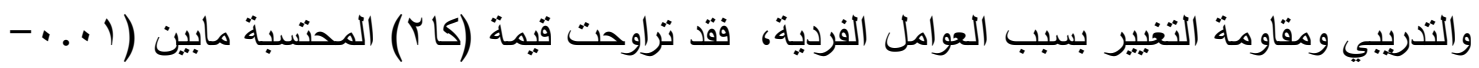

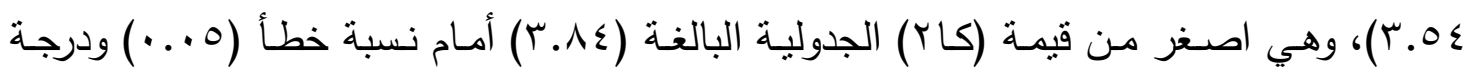

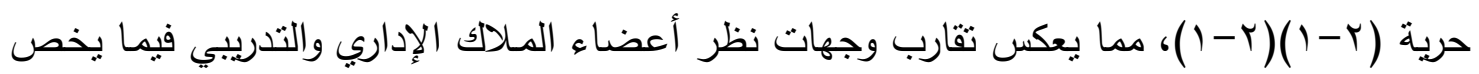

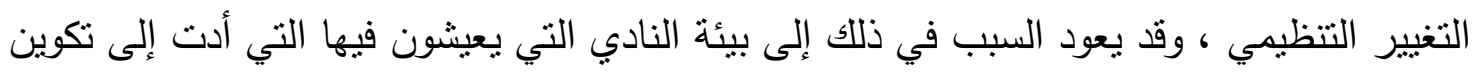

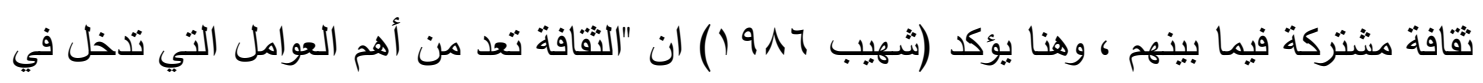

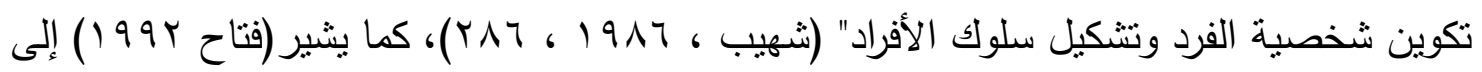

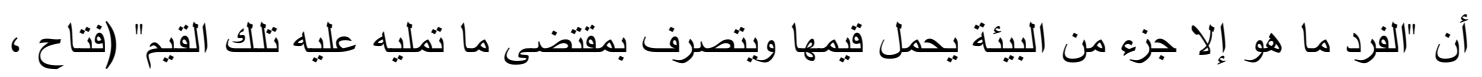
. (17 ، 1994

\section{•-الاستنتاجات والتوصيات

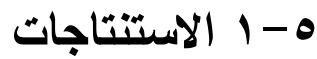

ا. لا توجد علاقة معنوية بين نوع الملاك (الإداري-التدريبي) ومقاومة التغيير بسبب العوامل

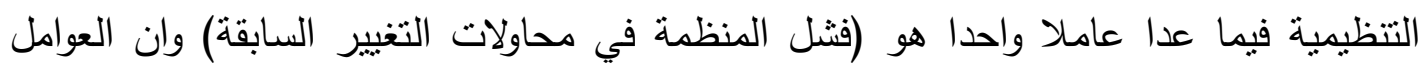
المشتركة والمسببة لمقاومة التغيير بالنسبة إلى الملاكين هي (احتمال بقاء نظام المكافآت، والتتافس والصراع).

rTY 
r. لا توجد علاقة معنوية بين نوع الملاك (الإداري-التدريبي) ومقاومة التغيير بسبب العوامل

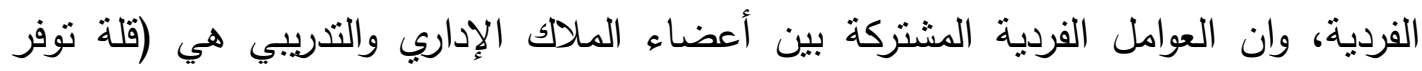
المعلومات وعدم فهم أهداف التغيير، تضارب الأهداف الفردية والتنظيمية).

\section{ه-r التوصيات}

ا • يجب أن تكون محاولات التغيير في الأندية الرياضية مقبولة لدى الملاكين الإداري والندريبي عن طريق مصاحبة التغيير بنظام حوافز معنوية كالإغناء الوظيفي ونظام الترقيات.

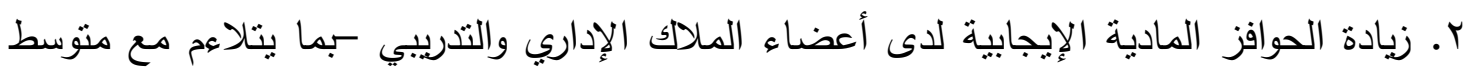

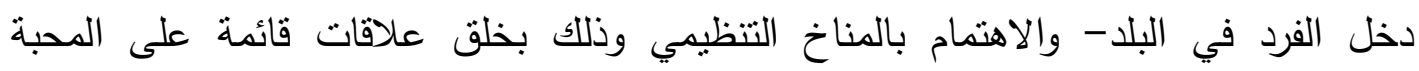

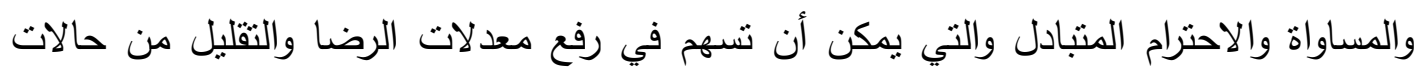
التنافس والصراع المصاحب للتغيير . r.إجراء دراسة عن الأسباب النفسية لمقاومة التغيير وعلاقتها بالسمات الثخصية لأعضاء الملاك

$$
\text { الإداري والتدريبي. }
$$

ع. إجراء دراسة عن مقاومة التغيير وعلاقتها ببعض الخصائص الثخصية كالانحدار الحضري والتحصيل الدراسي ومدة الخدمة والدورات التدريبية لأعضاء الملأك الإداري والتنريبي.

\section{المصادر}

1. أبو حطب وآخران (1999) :التقويم النفسي ، طب ، مكتبة الانجلو المصرية ، القاهرة.

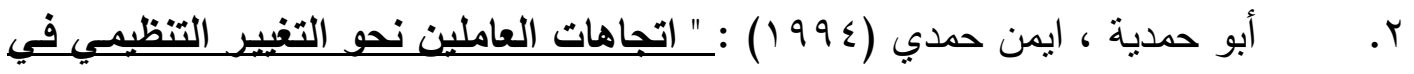

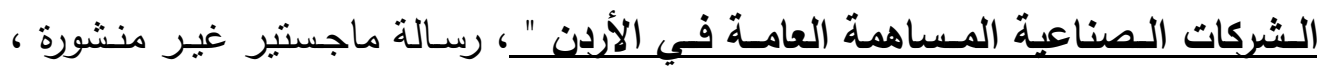

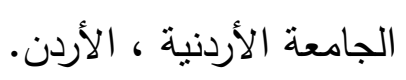

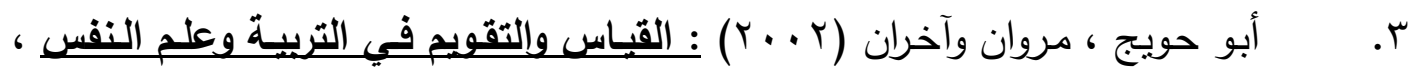
طا ، الدار العلمية الدولية للنشر والتوزيع ، عمان.

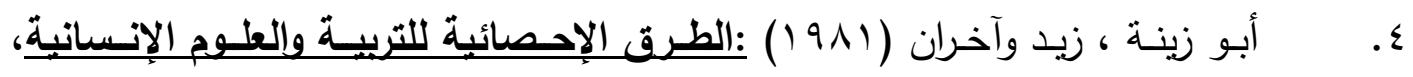
ج ا كدار الفرقان للنشر ،عمان.

$r r v$ 
ه. الاعرجي ، عاصم (1997) : إدارة الأزمـات واتخـاذ القـرارات ، طا ، دار مؤسسة حمادة للنشر ، اربد.

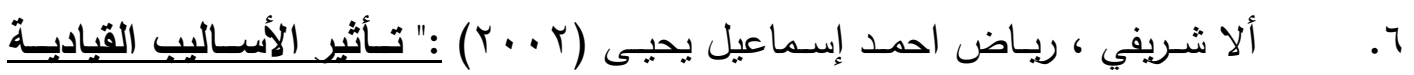

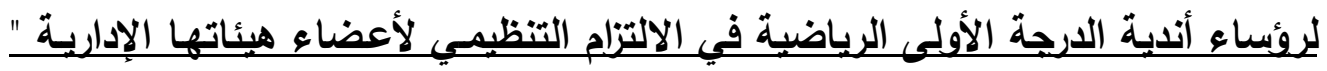
أطروحة دكتوراه غير منشورة،جامعة الموصل،كلية التربية الرياضية.

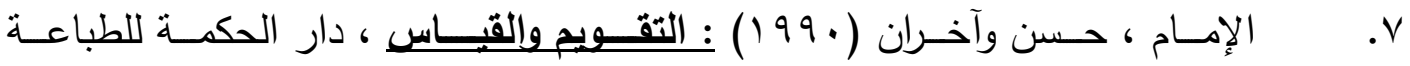

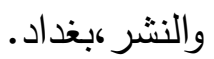

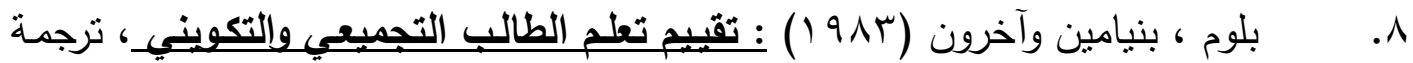

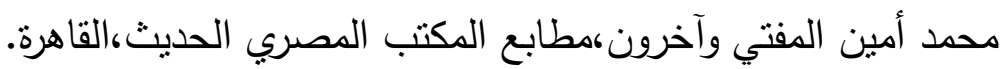

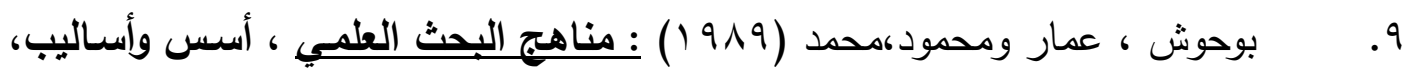

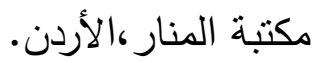

• 1. التكريني ، وديع ياسين والعبيدي ، حسن محمد عبد (1999) : التطبيقات الإحصائبة

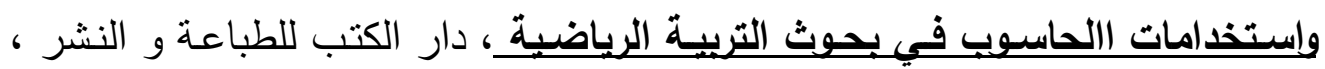

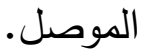

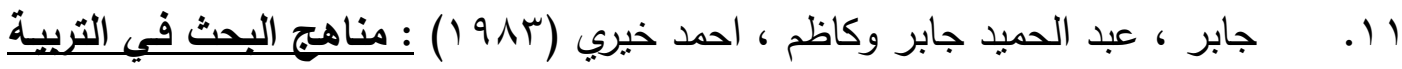
وعلم النفس ، دار النهضة العربية، القاهرة. r ا. حريم ، حسين (9991 ) : السلوك التنظيمي ، سلوك الأفراد في المنظمـات ، دار زهران للنشر والتوزيع ، عمان.

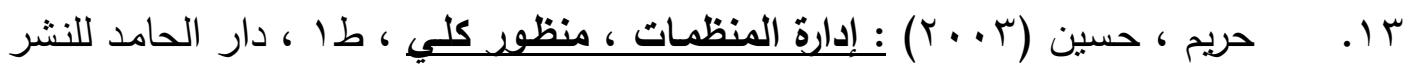

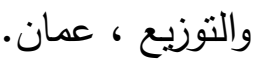

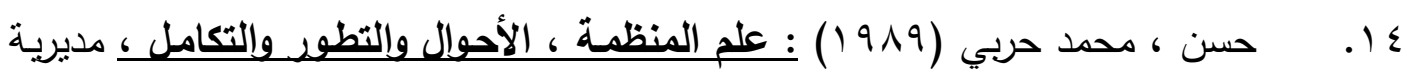
دار الكتب للطباعة والنشر ، جامعة الموصل.

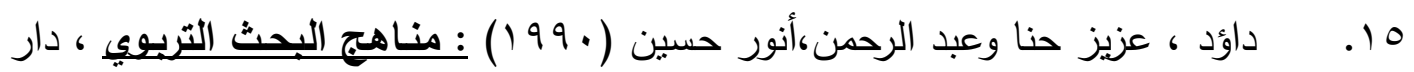
الحكمة للطباعة والنشر ،جامعة بغداد.

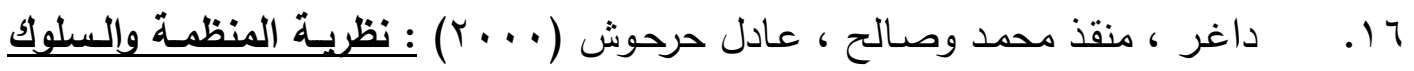
التنظيمي، مديرية دار الكتب للطباعة والنشر ،بغداد.

rTh 


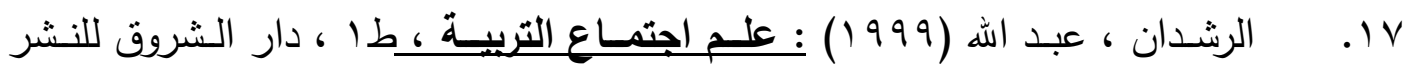
والتوزيع ، عمان. (- مان.

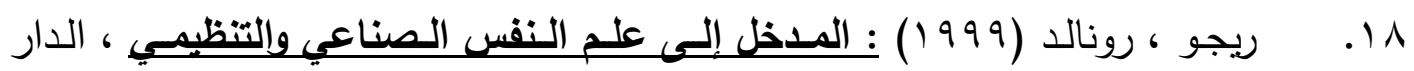
الجامعية للطباعة والنشر ، الإسكندرية

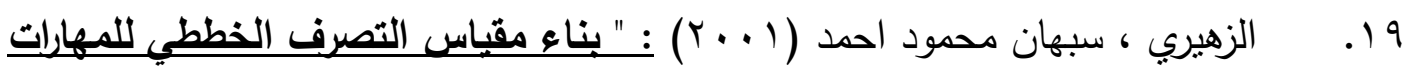
المفتوحة والمغلقة بالتس الأرضي في اللعب الفردي وعلاقته بالذكاء وعدد من مظاهر

الانتباه " أطروحة دكتوراه غير منشورة ،جامعة الموصل ، كلية التربية الرباضية.

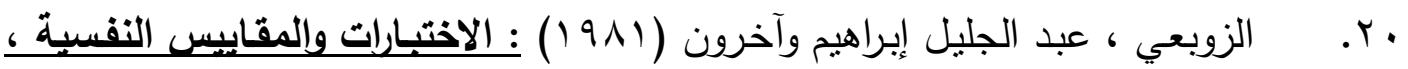
مطبعة جامعة الموصل، الموصل.

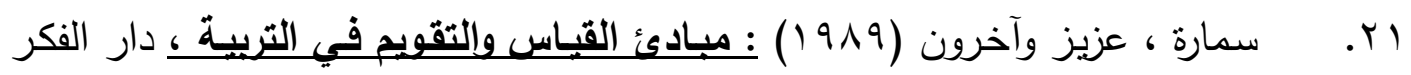
للنشر والتوزيع، عمان

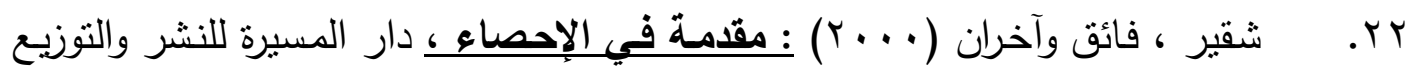
والطباعة ، عمان.

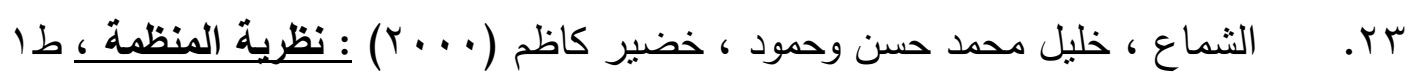
، دار المسيرة للنشر والتوزيع والطباعة ن عمان.

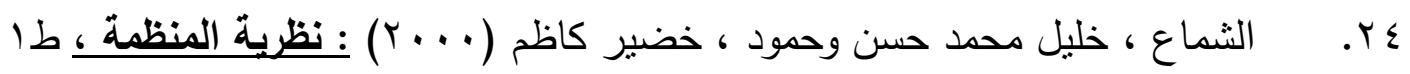
، دار المسيرة للنشر والتوزبع والطباعة ن عمان.

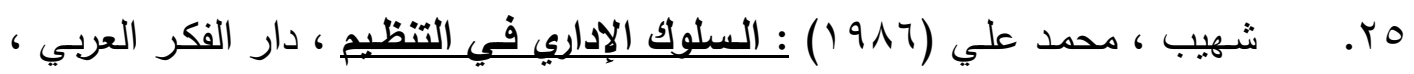
القاهرة

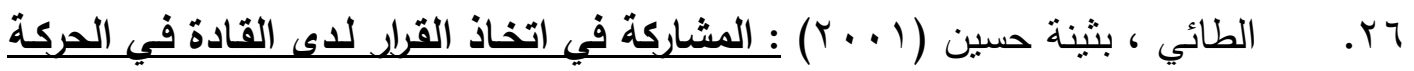
الكـشفية وعلاقتهـا بالـضفوط المهنــة ، رسـالة ماجستير غيـر منشورة ، كليـة التربيـة الرياضية ، جامعة الموصل. V V. العزاوي ، أباد عبد الكريم وإبراهيم ، مروان عبد المجيد (r . . r) : علم الاجتماع التريوي

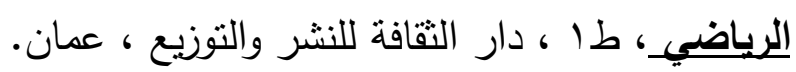

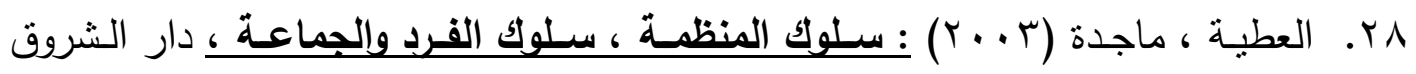
للنشر والتوزيع ، الأردن. 
9. دار الفكر العربي ، القاهرة.

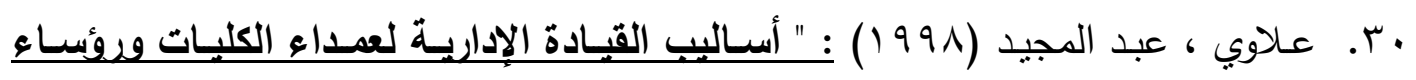

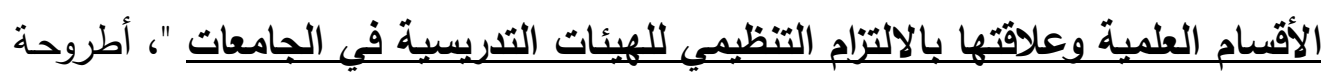

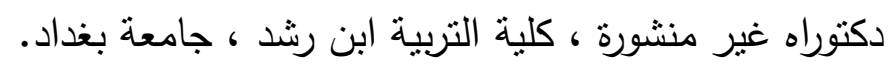

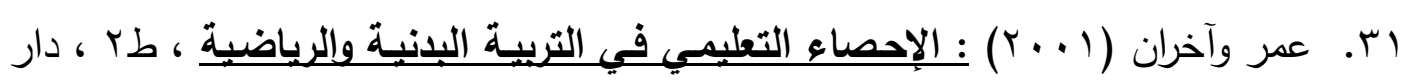
الفكر العربي ، القاهرة.

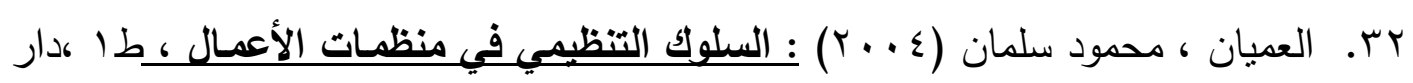
وائل للنشر ، عمان.

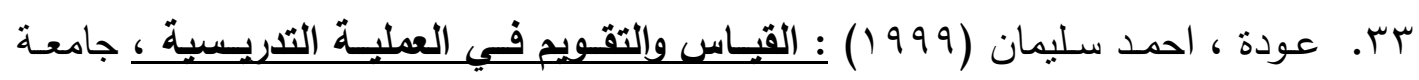

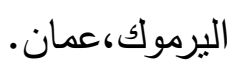

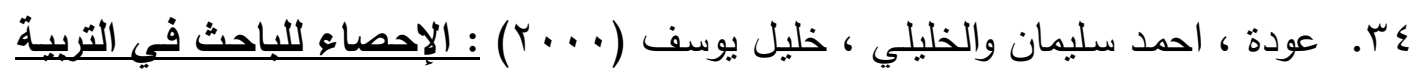
والعلوم الإنسانية ، دار الفكر ، عمان.

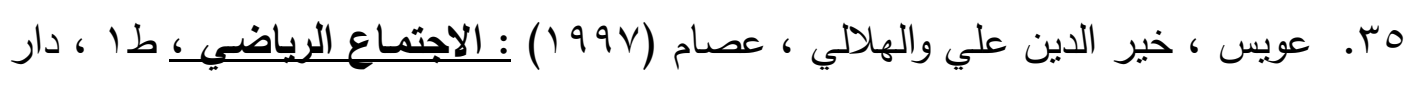
الفكر العربي ، القاهرة.

جس. الغريب ، رمزية (1910) : التقويج والقياس النفسي والتريوي ، مكتبة ألا نجلو المصرية ، القاهرة.

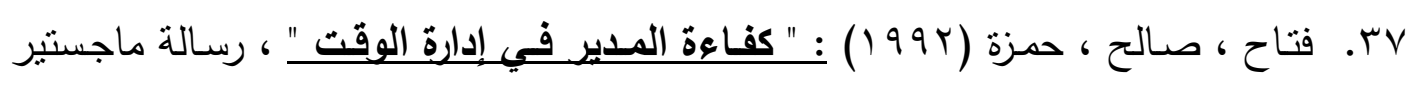

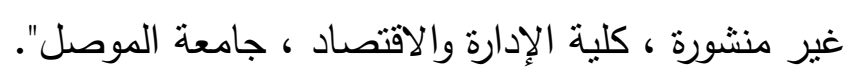

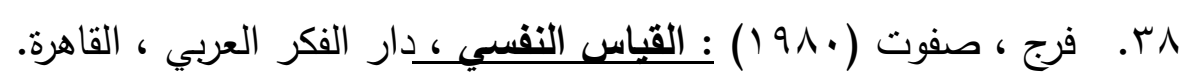

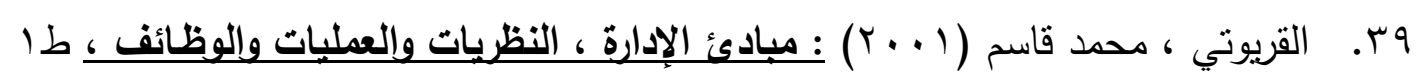

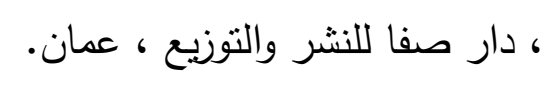

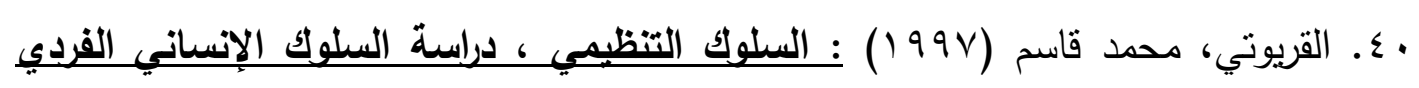

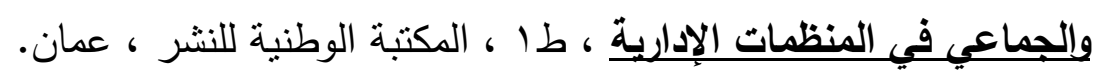

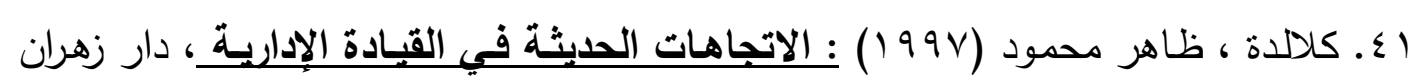
للطباعة والنشر ،عمان.

r $\varepsilon$. 


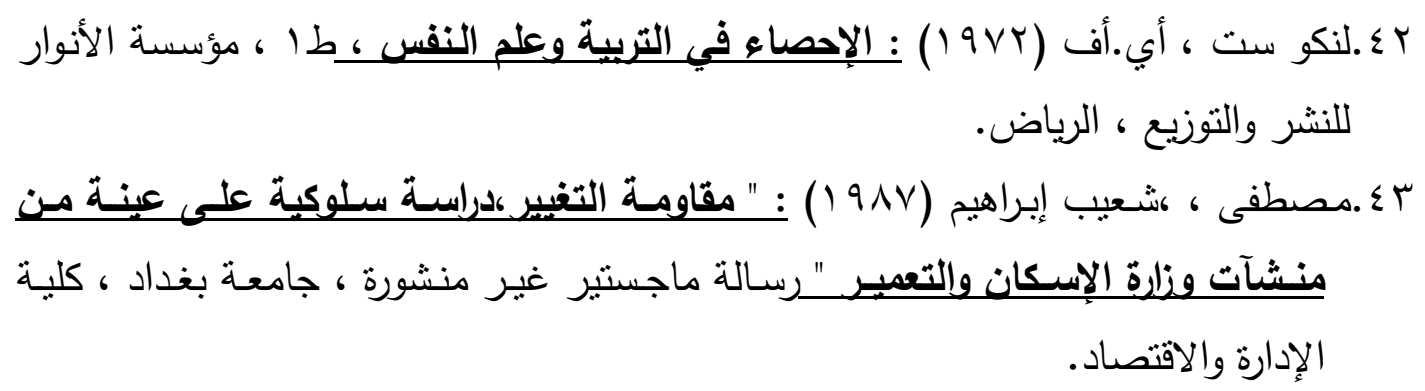

44. Anastasi (1976): Psychological Testing, (4 ${ }^{\text {th }}$ Ed), Macmillan publishing, New York.

45. Bovey.Wayne.H (2003): "Resistance to organizational change: the role of defense mechanisms", Journal of Managerial Psychology.Vol(16).NO(7) WWW.mcbup.com./registers.

46. Burton, Richard.M (2004):"'Tension and Resistance to change in organizational climate,managerial implication for a fast paced world",SUD-Odense university,Denmark_www.boe@ sam.sdu.dk .

47. Goldberg, S\&Denet, E (2003): Challenging"Resistance to change", Journal of Applied Behavioral Science. www.amorenaturalway.com

48. Skarlick,D\&Folger,R(2002) :unfairness and resistance to change:Hardship as mistreatment,Journal of Organizational Change management.・www.odnetwork@ ODNetwork.org. 